A N N A L E S

UNIVERSITATIS MARIAE CURIE-SKŁODOWSKA

LUBLIN - POLONIA

VOL. LXVI, 2

SECTIO G

2019

Uniwersytet Wrocławski

MAREK MACIEJEWSKI

marek.maciejewski@uwr.edu.pl

ORCID: 0000-0002-5296-1394

\title{
Rola wojennych idei roku 1914 w rozwoju niemieckiego nacjonalizmu
}

The Role of the Warfare Ideas of 1914 in the Development of German Nationalism

Wybuch w 1914 r. wojny światowej - jak się miało okazać ćwierć wieku później pierwszej z dwóch wojen o globalnym zasięgu - był jednym z najbardziej przełomowych wydarzeń w dziejach Niemiec oraz wielu innych państw Starego Kontynentu i pozaeuropejskich. Jeszcze większe i dalekosiężne skutki - tak negatywne, jak i pozytywne, w zależności od określonego punktu widzenia - wywołało zakończenie tej wojny w 1918 r. po ponad czterech latach okrutnych i wyniszczających walk między jej uczestnikami. W połowie 1914 r. niewielu polityków, wojskowych i przedstawicieli innych elit w Europie, nie mówiąc już o zwykłych mieszkańcach, zdawało sobie jednak z tego sprawę. Rzadko kto przewidywał wtedy rozmaite, dotkliwe, a nawet bolesne konsekwencje tej wojny światowej: upadek imperiów europejskich, rozpad wartości mieszczańskich i arystokratycznego etosu, kryzysy polityczny, społeczny czy gospodarczy, lewicowe fale rewolucyjne, walki o granice państwowe, powstania narodowe, utworzenie pierwszego państwa komunistycznego na świecie oraz powstanie na gruzach przedwojennych monarchii nowych państw w środkowo-wschodniej części Europy. Jednym z nielicznych polityków, którzy dostrzegali takie niebezpieczeństwa, był kanclerz Rzeszy Theobald von Bethmann Hollweg, który pod koniec lipca 1914 r. wyraził pogląd: „Widzę zagładę większą niż moc człowieka wiszącą nad Europą i naszym narodem". Uważał on wojnę za „skok w mrok”. Pod tym względem prorocze okazały się także słowa ministra spraw zagranicznych Wielkiej Brytanii Edwarda

1 Cyt. za: I. Kershaw, Do piekła i z powrotem. Europa 1914-1949, Kraków 2016, s. 29. 
Greya z początku sierpnia tego roku. Metaforycznie napisał wtedy: „W Europie gasną światła". A przecież wojna się wówczas dopiero zaczynała. Co więcej, najbardziej okrutne i krwawe wydarzenia wojenne jeszcze się w ogóle nie rozgrywały. Wszystko co najgorsze miało dopiero nadejść. Można w związku z tym za Robertem Gerwarthem przyjąć, że wojna światowa wcale nie zakończyła się pod koniec 1918 r., lecz trwała jeszcze przez kilka następnych lat, choć nie przybierała już form międzynarodowego konfliktu militarnego ${ }^{2}$. Około połowy $1914 \mathrm{r}$. w zasadzie nikt w Europie nie zakładał jednak takiego czarnego scenariusza przyszłych wydarzeń, które miały wstrząsnąć Starym Kontynentem, a nawet zburzyć jego polityczno-społeczną konstrukcję. Bezpowrotnie do przeszłości przeszły po zakończeniu wojny światowej kojarzone z fin de sièclem czy z la belle èpoque czasy mieszczańskiej stabilności, utrwalanego od dawna porządku politycznego opartego na dominacji wielkich mocarstw, a nawet pewnej beztroski cechującej zwłaszcza wyższe warstwy społeczne. Pewne symptomy nadchodzących zmian w tych dziedzinach dało się zresztą zauważyć niedługo przed wybuchem I wojny światowej ${ }^{3}$. Prawdopodobnie żadna licząca się siła polityczna przedwojennego, wydawałoby się trwałego i silnego, establishmentu nie była w latach 1917-1919 w stanie skutecznie zapobiec wymienionym przemianom i procesom dziejowym. W gruncie rzeczy stare reżimy Romanowów, Hohenzollernów i Habsburgów okazały się wobec nich bezsilne oraz zaskoczone utratą swej uprzywilejowanej pozycji państwowej. Dawna Europa z niemal wszystkimi swoimi fundamentami i filarami ustrojowymi, militarnymi czy gospodarczymi - monarchiami, rządami autorytarnymi, potężnymi siłami zbrojnymi, kapitalistycznym bogactwem, strefami wpływów, zamorskimi koloniami, podporządkowanymi sobie narodami pozbawionymi własnej państwowości - zaledwie w ciągu kilku lat drugiej dekady XX w. rozsypała się jak przysłowiowy domek z kart. Raz jeszcze powtórzę - w 1914 r. niemal nikt się o to nie martwił ani się tym nie przejmował, wierząc w pomyślny dla siebie przebieg działań militarnych.

Gdy po udanym zamachu na życie habsburskiego następcy tronu arcyksięcia Franciszka Ferdynanda w Sarajewie w dniu 28 czerwca 1914 r. kolejne państwa

2 R. Gerwarth, Pokonani. Dlaczego pierwsza wojna światowa się nie zakończyła (19171923), Poznań 2017. Literatura o I wojnie światowej jest już dość obszerna, a niedawna rocznica stulecia jej wybuchu spowodowała wzrost liczby opracowań naukowych na ten temat. Tylko w Polsce ukazały się ostatnio m.in. następujące książki: A. Chwalba, Samobójstwo Europy. Wielka wojna 1914-1918, Warszawa 2014; P. Ham, 1914. Rok końca świata, Warszawa 2015; M. Gilbert, Pierwsza wojna światowa, Poznań 2003; J. Holzer, Europa wojen 1914-1945, Warszawa 2008; J. Pajewski, Pierwsza wojna światowa 1914-1918, Warszawa 2009; A. Wiest, Historia I wojny światowej, Warszawa 2003.

3 Interesująco pisze o tym kanadyjski historyk łotewskiego pochodzenia Modris Eksteins w niedawno opublikowanej w Polsce książce Święto wiosny. Wielka wojna i narodziny nowego wieku (Poznań 2014), podając jako dobitny przykład owych zmian symptomatyczne reakcje na wystawienie baletu Igora Strawińskiego pod takim samym tytułem. 
europejskie zaczęły na przełomie lipca i sierpnia tego roku wypowiadać sobie wojnę, większość mieszkańców tych krajów (szczególnie Niemiec, Francji i Austro-Węgier) ogarnął niemal entuzjazm, radość czy uniesienie z tego powodu. Przez wielu z nich wojna była wręcz wyczekiwana - jako coś oczywistego i koniecznego, nabierając w społecznym odczuciu, zwłaszcza na początku działań militarnych, cech metafizycznego spektaklu teatralnego, który wyrażał walkę z rozmaicie pojmowanym złem, słabością, zakłamaniem czy obłudą. Na ulice i place Berlina, Wiednia, Paryża czy Moskwy wychodziły latem 1914 r. - jak wynika z wielu relacji świadków tych burzliwych wydarzeń ${ }^{4}$ - tłumy ludzi manifestujących swoje prowojenne postawy, oczekujących rychłego zwycięstwa w walce z przeciwnikami, wprost zagrzewających władze państwowe do użycia sił militarnych przeciwko zewnętrznym wrogom. Na czas tej niebywałej mobilizacji uczuć patriotyczno-nacjonalistycznych, z całą mocą ujawnionych latem $1914 \mathrm{r}$., zaczęły schodzić na dalszy plan podziały polityczne między prawicą i lewicą. Niemal nikt spośród piastunów władzy czy przedstawicieli społeczeństwa Niemiec, Austro-Węgier czy Francji nie chciał stać z boku rozgrywających się wtedy wydarzeń, lecz na ogół starał się w nie angażować. Oczywiście zdarzały się głosy przestrogi (jak np. Bertranda Russella czy Stefana Zweiga), lecz były one słabo słyszalne. Nawet raczej pacyfistycznie nastawieni niemieccy socjaldemokraci dali się wówczas unieść prowojennej psychozie i ostatecznie poparli starania rządu o zwiększenie subwencji na cele militarne. Na łamach jednej z należących do nich gazet („Bremer Bürger-Zeitung”) pojawił się w związku z tym nagłówek: „Spełnij swój straszliwy obowiązek" "Żaden Niemiec nie powinien się od niego uchylać - taka była wymowa tego wyraźnego polecenia. Nie trzeba było zresztą Niemców szczególnie do tego namawiać. Większość z nich pragnęła bowiem dobrowolnie wziąć udział w zbliżającej się wojnie. Co więcej, odczuwali wewnętrzną potrzebę służby dla ojczyzny na polach bitewnych, by móc wykazać się odwagą, męstwem i poświęceniem dla niej. Taka postawa wydawała się w tamtym okresie czymś zupełnie zrozumiałym i wskazanym. W dodatku zachęcał do niej cesarz Wilhelm II pod koniec lipca 1914 r. Do tłumów zebranych przed swym pałacem w Berlinie mówił: „Na wojnie, która nas czeka, moi ludzie nie dzielą się już na partie. Odtąd są wśród nas tylko Niemcy" posądzony o brak patriotyzmu czy defetyzm, zwłaszcza że w obliczu zbliżającej się wojny coraz bardziej dominujące okazywały się (nie tylko w Rzeszy) nastroje dumy, jedności i wspólnoty narodowej. Można przyjąć, że wprost rozkwitały

4 Pisał o tym m.in. sekretarz kanclerza Rzeszy Kurt Riezler w książce Tagebücher, Aufsätze, Dokumente (Hrsg. K.D. Erdmann, Göttingen 1972, s. 43 i n.). Zob. także: M. Hürlimann, Berlin, Zürich 1981, s. 193.

5 Cyt. za: D. Groh, Negative Integration und revolutionärer Attentismus, Frankfurt am Main 1973, s. 675.

6 I. Kershaw, op. cit., s. 66. 
wtedy tendencje nacjonalistyczne, nierzadko o cechach antysemickich i rasistowskich. Nigdy wcześniej nie wystąpiły one w Niemczech z takim nasileniem, jak w tamtym okresie. Aż tak wyraźne i powszechne owe nastroje i tendencje nie były nawet w dobie tworzenia zjednoczonej Rzeszy w drugiej połowie XIX w.

Z tych wszystkich względów wojnę traktowano w Niemczech w $1914 \mathrm{r}$. nie tylko jako konflikt militarny z zewnętrznym przeciwnikiem przy użyciu siły zbrojnej, czyli czynników materialnych i technicznych, które oczywiście uważano za ważne. Wielu Niemców (podobnie jak Brytyjczycy czy Francuzi) upatrywało $\mathrm{w}$ ówczesnych osiągnięciach $\mathrm{w}$ tej dziedzinie wspaniałego wytworu potęgi ludzkiego rozumu i przejawu niebywałego postępu cywilizacyjnego, napawających dumą i wywołujących powszechny zachwyt. Niektórych przyprawiały one nawet o zawrót głowy - aż tak były nowoczesne i znakomite, jak na tamte czasy. Choć technologiczny aspekt i wymiar wojny okazał się niezwykle istotny, to jednak nie wyczerpywał jej sedna. Nie mniej ważna, a nawet jeszcze ważniejsza, stała się w 1914 r. symboliczna warstwa działań militarnych. Często rozpatrywano bowiem wojnę w kategoriach ideowych mieszczących się w sferze świadomości narodowej i z niej wyrastających. Wojna miała zatem - jak można przyjąć - stanowić Heglowskie ucieleśnienie absolutnego ducha narodu. Jak utrzymywał na początku sierpnia 1914 r. pełen patosu nacjonalista i liberał Theodor Heuss, wojna powinna być przejawem „moralnej wyższości, moralnej siły i moralnej racji” Niemców ${ }^{7}$ Już w 1911 r. inny niemiecki pisarz, Friedrich von Bernhardi, upatrywał w zbliżającej się światowej wojnie ,życiodajnej zasady” każdej istoty ludzkiej. Szczególny walor wojny dostrzegał w jej roli kulturotwórczej ${ }^{8}$. Wojna miała być źródłem nie każdej kultury, ale głównie kultury najwyższej, czyli najbardziej „wysublimowanej, doskonałej i wzniosłej”. W przekonaniu Bernhardiego taka właśnie kultura cechuje Niemców w odróżnieniu od innych, mniej cywilizowanych narodów. Wojnę ujmowano w tamtym okresie również jako sprawę ludzkiej woli, bez której nie mogłaby się ona urzeczywistnić. Gotowość Niemców do prowadzenia wojny miała - jak twierdził w sierpniu $1914 \mathrm{r}$. liberalny lewicowiec Conrad Hausmann - wynikać z indywidualnej woli każdego z nich „potwierdzenia samego siebie" ". Wojna kojarzyła się wreszcie Niemcom, głównie z kręgów artystycznych, na samym jej początku w tamtym roku z wewnętrzną wolnością samorealizacji swych wizji oraz z wyzwoleniem od ciasnoty myślowej, małostkowości, konwenansów, banału czy hipokryzji.

Tak oto narastało w wilhelmińskiej Rzeszy umiłowanie dla wojny jako przeżycia etycznego i estetycznego, czegoś wzniosłego i pięknego w swej formie i treści, swego rodzaju zjawiska filozoficznego i metafizycznego zarazem. Wraz z nim

7 T. Heuss, Der Weltkrieg, „März“, 5 VIII 1914, s. 221.

8 F. Bernhardi, Germany and the Next War, New York 1914, s. 18.

9 C. Hausmann, Europas Krieg, „März“, 22 VIII 1914, s. 250. 
rodził się kult wojny - ponad podziałami społecznymi i w poprzek podziałów politycznych. Wokół niej dokonywała się latem 1914 r. niemal totalna mobilizacja narodowo myślących Niemców, czyli przytłaczającej większości z nich. Nieliczne głosy sprzeciwu wobec wojny - o czym już wspomniałem - słabo przebijały się do ogarniętej jej ideą opinii publicznej. Nie będzie przesady w twierdzeniu, że Niemców ogarnął niemal szał prowojennej retoryki. Ulegli mu nawet, czasem nie bez pewnych oporów, wybitni intelektualiści, jak choćby Thomas Mann ${ }^{10}$. Zbliżająca się wojna światowa jednoczyła Niemców wokół osoby cesarza Wilhelma II, który zyskał wtedy taką popularność, jakiej nie miał nigdy wcześniej. Wszystkie wskazane sposoby pojmowania wojny złożyły się na nacjonalistyczny w swej wymowie, powstały w Rzeszy tuż przed wybuchem I wojny światowej i w początkowym okresie jej trwania, zespół poglądów zbiorczo określanych w literaturze politycznej i naukowej jako idee roku $1914^{11}$. Jak się jeszcze przekonamy, stały się one jedną ze szczególnie ważnych przesłanek rozwoju powojennego nacjonalizmu niemieckiego, przede wszystkim w okresie Republiki Weimarskiej, w której długo borykano się z negatywnymi skutkami klęski militarnej Rzeszy w 1918 r. Mimo że wojna światowa zakończyła się dla niej upadkiem władzy Hohenzollernów i autorytetu państwa, wciąż żywe były w Niemczech - jakby na przekór faktom - idee roku 1914. Po zakończeniu wojny nabrały one nawet jeszcze bardziej mistycznego, a zwłaszcza nacjonalistycznego znaczenia niż w okresie poprzedzającym jej wybuch. Często odwoływano się wtedy do nich, zachęcano do wzorowania się na militarnym etosie, wspominano i czczono wojennych bohaterów. Znaczny wpływ na ukształtowanie się w latach 1918-1933 wspartego na kulcie odwagi, męstwa, patriotyzmu i wspólnoty narodowej niemieckiego nacjonalizmu wywarły doktryny tzw. rewolucji konserwatywnej (konservative Revolution). To głównie w nich zostały przechowane i wzbogacone o nowe elementy idee roku 1914. W doktrynach tych dokonała się nawet sakralizacja tych idei - poprzez nadanie im niemal religijnego wymiaru jako wyznania wiary w nieograniczone możliwości ludzkiej natury zdolnej do największych uniesień i poświęceń oraz osiągnięć technologicznych. Należy dodać, że do idei roku 1914 odwoływały się po I wojnie światowej także inne nacjonalistyczne siły niemieckie. Owe koncepcje inspirowały m.in. nazistów, członków paramilitarnych formacji ochotniczych (Freikorps) czy organizacji o nazwie Stahlhelm. Żadna z nich nie nadała jednak ideom roku 1914 tak rozbudowanej oprawy ideologicznej, jak rewolucyjni konserwatyści. Dla nich stały się one wręcz zasadniczym elementem uzasadniającym głoszone przez tych myślicieli hasła nacjonalistyczne.

10 Wyraz swemu oczekiwaniu na coś zupełnie nowego i pozytywnego, co przyniesie wojna, dał w Czarodziejskiej górze (Warszawa 1956, s. 20). Z kolei Friedrich Meinecke (Strassburg Freiburg - Berlin, Stuttgart 1949, s. 137 i n.) pisał o dreszczach emocji, gdy wspominał nastroje społeczne w Niemczech w sierpniu $1914 \mathrm{r}$.

11 Do kwestii owych idei nawiążę jeszcze w dalszej części artykułu, powołując odnośną literaturę. 
Koncepcje rewolucji o cechach konserwatywnych czy też konserwatyzmu zabarwionego rewolucyjnie (na ten temat trwają spory naukowców) rozwijały się od końca I wojny światowej przede wszystkim wśród nacjonalistycznych i antydemokratycznych odłamów niemieckich warstw inteligenckich oraz tego rodzaju grup w niektórych innych państwach europejskich (zwłaszcza we Francji i Włoszech). Ta zrodzona z kryzysu mieszczańskich wartości liberalnych doktryna, a w zasadzie zespół doktryn o zróżnicowanej treści politycznej, prawnej czy społecznej, odzwierciedlała znamienne dla całego społeczeństwa niemieckiego po 1918 r. nastroje niezadowolenia, zwątpienia i bezsilności spowodowane klęską militarną w wojnie światowej, upadkiem cesarstwa Hohenzollernów oraz głębokim kryzysem politycznym i ekonomicznym w tym okresie. Skomplikowaną sytuację wewnętrzną w ówczesnej Rzeszy jeszcze bardziej zaostrzała szerząca się po I wojnie światowej propaganda nacjonalistyczna, która uporczywie głosiła tezę o „ciosie” zadanym Niemcom „w plecy” (Dolchstoss) przez siły lewicy, „międzynarodowe żydostwo" i państwa Ententy ${ }^{12}$. Do utwierdzania niemieckiego społeczeństwa w takim przekonaniu przyczyniali się swymi poglądami zarówno rewolucyjni konserwatyści, jak i inne elementy nacjonalistyczne, a zwłaszcza narodowi socjaliści. Reprezentowana przez nazistów ideologia - niemal pozbawiona cech oryginalności i oparta na różnego rodzaju naśladownictwie - w znacznej mierze powielała zresztą społeczne i polityczne koncepcje „rewolucji konserwatywnej”. Na temat wpływu w sferze doktrynalnej rewolucyjnego konserwatyzmu na narodowy socjalizm pisałem już we wcześniejszych opracowaniach ${ }^{13}$. Jeden z głównych czynników łączących oba nurty myśli politycznej stanowił właśnie nacjonalizm, choć jego założenia nie były w nich identyczne. Dodam, że nacjonalizm w ujęciu nazistowskim był bardziej prymitywny, a na pewno nie tak przeintelektualizowany jak nacjonalizm myślicieli uważających się za rewolucyjnych konserwatystów. Co by nie powiedzieć, potrafili oni uczynić z niego osnowę dla całej swej ideologii. Do nacjonalizmu nawiązywały bądź wprost z niego wynikały niemal wszystkie składniki doktryny „,rewolucji konserwatywnej", a zatem antyliberalizm, antyparlamentaryzm, imperializm, solidaryzm społeczny, tzw. niemiecki socjalizm, kult wojny, zwłaszcza zaś koncepcja wspólnoty narodowej (Volksgemeinschaft). Nacjonalistyczne przesłanki wycisnęły piętno również na nazwie omawianej doktryny. W pełni przekonująco brzmi teza Franciszka Ryszki, że wzbogacony o „elementy socjalne” nacjonalizm wybijał się „na plan pierwszy” w ideologii rewolucyjnego konserwatyzmu ${ }^{14}$.

12 Szerzej o tym por. J. Petzold, Die Dolchstosslegende. Eine Geschichtsfälschung im Dienst des deutschen Imperiatismus und Militarismus, Berlin 1963, passim; A. Rosenberg, Dolchstossdokumente. Zeugnisse der Vorbereitung zur Revolte am 9. November 1918, München 1926, s. 3, 47 i n.

13 Przede wszystkim w monografiach: Doktryna rewolucyjnego konserwatyzmu wobec narodowego socjalizmu 1921-1945, Wrocław 1991; Niemieckie elity a hitleryzm. O stosunku rewolucyjnych konserwatystów do nazizmu w Rzeszy demokratycznej i hitlerowskiej, Wrocław 1994.

14 F. Ryszka, Intelektualiści a hitleryzm (Szkic o „rewolucji konserwatywnej” w Niemczech), 
Dla określenia istoty tej doktryny niektórzy jej przedstawiciele (m.in. Ernst Jünger) posługiwali się pojęciem „nowy nacjonalizm” w celu jego odróżnienia od niemieckiego nacjonalizmu sprzed 1914 r. Kształtowanie się tego nacjonalizmu przypadło na okres, w którym w Europie (szczególnie we Francji) rozwijał się po I wojnie światowej tzw. nacjonalizm integralny (całościowy) ${ }^{15}$. W odróżnieniu od „starego" nacjonalizmu, występującego głównie wśród wyższych warstw społecznych i cechującego się zachowawczą postawą polityczną wyrażającą się $\mathrm{w}$ obronie status quo, odznaczał się on sporym radykalizmem, dynamizmem i agresywnością, emocjonalnym i z reguły irracjonalnym, a niekiedy także rasistowskim podejściem do kwestii narodowych oraz silnym dążeniem do stworzenia państwa narodowego. Uprzedzając dalsze wywody, można przyjąć, że „nowy nacjonalizm" rewolucyjnych konserwatystów stanowił jeden z niemieckich wariantów europejskiego nacjonalizmu integralnego, a nawet jego najbardziej wyraźny przejaw w Rzeszy po I wojnie światowej. W ten sposób określa się zresztą istotę omawianej przeze mnie doktryny w nowszej literaturze naukowej dotyczącej rewolucyjnego konserwatyzmu ${ }^{16}$. Nadmienię, że w starszych opracowaniach na ten temat raczej tak wyraźnie nie eksponuje się znaczenia owego nacjonalizmu, zwracając bardziej uwagę na inny aspekt ideowy, mianowicie na konserwatywny z przyrostkiem „neo" charakter rewolucyjnego konserwatyzmu ${ }^{17}$. Jego twórcy po I wojnie światowej przynajmniej częściowo odcinali się od założeń tradycyjnego światopoglądu konserwatywnego z XIX w. i początku następnego stulecia, określając się w związku z tym niekiedy właśnie mianem nowych konserwatystów lub młodokonserwatystów (Jungkonservativen). Równocześnie pragnęli uchodzić za rewolucjonistów, zwłaszcza wtedy, gdy odnosili się do otaczającej ich rzeczywistości niemieckiej po 1918 r. Odrzucali ją a priori, niemal totalnie, bez jakichkol-

\footnotetext{
„Kwartalnik Historyczny” 1959, nr 2, s. 356; idem, Państwo stanu wyjątkowego. Rzecz o systemie państwa i prawa Trzeciej Rzeszy, Wrocław 1974, s. 59.

15 P. Lawrance, Nacjonalizm. Historia i teoria, Warszawa 2007, s. 123-124. Za czołowych przedstawicieli tego nacjonalizmu uważa się Charles'a Maurrasa i Maurice'a Barrèsa. Por. A. Wielomski, Nacjonalizm francuski 1886-1940. Geneza, przemiany i istota filozofii politycznej, Warszawa 2007, passim. W międzywojennej Polsce ten rodzaj nacjonalizmu głosił zwłaszcza Związek Młodych Narodowców. Por. W stronę autorytaryzmu. Nacjonalizm integralny Zwiazku Młodych Narodowców 1934-1939, wyb. i oprac. M. Marszał, Kraków 2008, s. VII i n. Odsyłam także do książki J. Bartyzela Prawica - nacjonalizm - monarchizm. Studia politologiczno-historyczne (Radzymin-Warszawa 2016) oraz do opracowania pod redakcją Bogumiła Grotta i Olgierda Grotta Nacjonalizmy różnych narodów. Perspektywa politologiczno-religioznawcza (Kraków 2012).

16 Dobitnie podkreślił znaczenie „,nowego nacjonalizmu” w tej doktrynie Stefan Breuer w monografii Anatomie der Konservativen Revolution (Darmstadt 1993), a za nim niektórzy inni autorzy, m.in. Rolf P. Sieferle (Die konservative Revolution. Fünf biographische Skizzen, Frankfurt am Main 1995), w Polsce zaś Wojciech Kunicki we wstępie do wyboru tekstów Rewolucja konserwatywna w Niemczech 1919-1933 (Poznań 1999, s. 7 i n.).

17 Przykładem jest monografia Martina Greiffenhagena Das Dilemma des Konservatismus in Deutschland (München 1971).
} 
wiek sentymentów. Po prostu traktowali istniejący wtedy stan rzeczy w polityce czy społeczeństwie jako coś nieprawdziwego - fantasmagorię, której należało się wyzbyć poprzez jej zniszczenie, a przynajmniej wymazanie ze świadomości. Można zasadnie stwierdzić, wyprzedzając tok dalszych wywodów, że dla rewolucyjnych konserwatystów ustrojowe formy powojennej Rzeszy z demokracją parlamentarną na czele były nie tylko nie do zaakceptowania. Oni zwyczajnie nie przyjmowali ich do wiadomości, energicznie starali się je zwalczać w swych poglądach i niekiedy również $\mathrm{w}$ działalności politycznej.

Wracając do kwestii nacjonalizmu reprezentowanego przez tych intelektualistów, należy podkreślić, że jako zwornik całej ideologii spod znaku ,rewolucji konserwatywnej" opierał się on na już częściowo omówionych przeze mnie wydarzeniach i procesach w 1914 r. Rodowód haseł odnoszących się do spraw narodowych twórcy owej doktryny dostrzegali w ukształtowanym przez generację Niemców uczestniczących w I wojnie światowej nowym, tj. bardziej holistycznym, ponadklasowym pojęciu patriotyzmu, ojczyzny i służby dla narodu ${ }^{18}$. Jeden z czołowych reprezentantów ideologii rewolucyjnego konserwatyzmu, Arthur Moeller van den Bruck, pisał w swym głównym dziele politycznym Das dritte Reich (1923):

$\mathrm{Z}$ ruin, które grożą pogrzebaniem wraz z państwem narodu wznosi się obecnie konserwatywno-rewolucyjny antyruch nacjonalizmu. Chce on życia narodu. Pragnie tego, czego chciało stare państwo [wilhelmińska Rzesza-M.M.] i każde państwo musi chcieć, lecz nie chce tego jako pojęcia, ale jako przeżycia. Chce nadrobić to, co zostało zaniedbane: udział narodu w swym przeznaczeniu ${ }^{19}$.

Neokonserwatywny nacjonalizm w Republice Weimarskiej był - jak się wydaje - jeszcze bardziej irracjonalny, choć nie mniej reakcyjny niż wcześniejsze koncepcje wynoszące niemiecki naród (Volk) ponad inne wartości i narody. W odróżnieniu od również przepojonego nacjonalizmem „starego" konserwatyzmu niemieckiego sprzed I wojny światowej nie polegał on na dążeniu do utrzymania „,̇ywotnych sił narodu i państwa” (co propagował konserwatywny ideolog Paul de Lagarde w jednym z artykułów z 1853 r. $)^{20}$, lecz na totalnym ,przewartościowaniu" niemal wszystkich wartości politycznych i społecznych w celu ukształtowania wspólnoty narodowej i zapewnienia jej możliwości terytorialnej ekspansji. Nacjonalizm neokonserwatystów w Republice Weimarskiej wyrastał ze znamiennego nie tylko dla Niemców rozbudzenia po 1918 r. poczucia narodowej odrębności, występującego zwłaszcza w tych państwach, które właśnie w tym okresie uzyskały niepodległość bądź za zagrożony uważały swój suwerenny byt. Nie bez racji twierdził w 1926 r. brat wspomnianego Ernsta Jüngera - Friedrich Georg,

18 Por. E. Jünger, ,Nationalismus “ und Nationalismus, „Das Tagebuch“ 1929, Heft 38 (September), s. 1552 i n.; F. Schauwecker, Wesen des Nationalismus, „Standarte“ 1926, Heft 16, s. 366 i n.

19 A. Moeller van den Bruck, Das dritte Reich, Hamburg 1931, s. 135.

20 Zob. P. de Legarde, Deutsche Schriften, München 1934, s. 19. 
że nacjonalizm jest „ruchem mającym przyszłość” dla wszystkich krajów kontynentu europejskiego. Z tego też względu ,popieranie” nacjonalizmu powinno stanowić „najważniejszy obowiązek tych, którzy obecnie zbierają się pod jego sztandarami i są przepełnieni jego świadomością"21.

Rewolucyjni konserwatyści rozmaicie definiowali pojęcie nacjonalizmu. We wszystkich próbach określenia sedna tego składnika neokonserwatywnej ideologii uwidaczniał się jednak charakterystyczny w ogóle dla tej doktryny mistycyzm wywodzący się z przejętych przez nią założeń „filozofii życia” (Lebensphilosophie) Friedricha Wilhelma Nietzschego i innych przedstawicieli tego kierunku w XIX i XX w. Na pojmowaniu nacjonalizmu przez rewolucyjnych konserwatystów zaciążyły również polityczne koncepcje niemieckiego romantyzmu dziewiętnastowiecznego, w których naród urastał do rangi najważniejszego dobra wymagającego szczególnej dbałości o jego rozwój. Reprezentujący neokonserwatywną ideologię Friedrich Wilhelm Heinz definiował nacjonalizm jako ,świadome i nieograniczone roszczenie państwowego, kulturalnego i gospodarczego urzeczywistnienia poprzez jedność wiary, krwi, historii, krajobrazu i mowy określonej duchowości wewnątrz nieograniczonego obszaru panowania, którego środek tworzą wszystkie niemieckie plemiona obejmujące Rzeszę"22. Ulegający irracjonalizmowi w ocenie zjawiska nacjonalizmu E. Jünger dowodził na łamach czasopisma „Standarte” z 1926 r., że światopogląd ten ,nie ma żadnych krytycznych, analizujących skłonności”, lecz „coś oszałamiającego, dziką, zgodną z krwią dumę, heroiczne, potężne poczucie życia". Nacjonalizm wydawał się temu rewolucyjnemu konserwatyście podobny do „elektrycznego bieguna w cieczy”, wymagającego dla swego ożywienia ,zewnętrznego impulsu", który powinien pochodzić od całego narodu niemieckiego, gdyż tylko taka zbiorowość mogła nadać „,nowy sens historyczny” pojęciom patriotyzmu i ojczyzny w warunkach społeczno-politycznego kryzysu po I wojnie światowej. Neokonserwatyści nie wiązali pojęcia nacjonalizmu z programem określonej partii politycznej w Republice Weimarskiej, choć niektórzy z nich uważali za orędowniczkę „sprawy narodowej” prawicowe Deutschnationale Volkspartei lub Deutsche Volkspartei, nawiązujące do tradycji cesarstwa Hohenzollernów i z tego względu raczej nieprzychylnie nastawione do ustroju republikańskiego w Niemczech po 1918 r. W nacjonalizmie dostrzegali ogólnonarodową ,burzliwą ideę” zrodzoną w walce $z$, duchowymi siłami” liberalizmu i ,socjalizmu o cechach marksistowskich"23. Jak z satysfakcją pisał F.G. Jünger w pracy pod wymownym tytułem

${ }_{21}$ F.G. Jünger, Die Kampfbünde, „Standarte“ 1926, Heft 1, s. 8-10.

22 Za: M. Hietala, Der neue Nationalismus in der Publizistik Ernst Jüngers und des Kreises um ihn 1920-1933, Helsinki 1975, s. 10. Por. K. Sontheimer, Antidemokratisches Denken in der Weimarer Republik. Die politischen Ideen des deutschen Nationalismus zwischen 1918 und 1933, München 1962, s. 154 i n.

23 M. Hietala, op. cit., s. 11. Por. W. Gerhart, Um das Reiches Zukunft. Nationale Wiedergeburt oder politische Reaktion?, Freiburg im Breisgau 1932, s. 78; E. Jünger, Der unsichtbare Kern, 
Aufmarsch des Nationalismus (1926), szerzący się w ówczesnych Niemczech nacjonalizm „rozbija partie i ich egoizm, który rozsadza państwo i niszczy jego żywotny sens". W neokonserwatywnej ideologii nacjonalizm uchodził nie tylko za czynnik poniekąd narodotwórczy, lecz także za przesłankę społecznej solidarności wszystkich Niemców, a nie tylko niektórych grup społecznych (przede wszystkim tzw. warstw wyższych), jak to miało miejsce w „starym” nacjonalizmie niemieckim.

Nacjonalizm nie zna podziału ludzi na klasy - czytamy w wydanym w 1927 r. opracowaniu pozostającej pod wpływem rewolucyjnego konserwatyzmu paramilitarnej organizacji Stahlhelm - ani też równości między narodami. Nacjonalizm widzi napędową siłę wszelkiego rozwoju w zdrowym narodzie, w rywalizacji między narodami. Nacjonalizm sam ma siłę rozwiązać kwestie socjalne, kryzys kapitalizmu i zarazę demokracji - w ramach własnego narodu i na bazie własnego państwa ${ }^{24}$.

Niektórzy reprezentanci neokonserwatywnej doktryny w Republice Weimarskiej (bracia Jüngerowie, Moeller van den Bruck, Oswald Spengler i inni) stawiali znak równości między założeniami „nowego nacjonalizmu” i socjalizmu o cechach narodowych, czyli tzw. niemieckiego bądź pruskiego socjalizmu. Jego cele nie miały nic lub prawie nic wspólnego z doktryną tzw. naukowego socjalizmu, czyli marksizmu-leninizmu, wykazując co najwyżej pewne podobieństwo do koncepcji lansowanych przez niemieckich socjaldemokratów. Mistyfikując nacjonalizm i socjalizm, rewolucyjni konserwatyści niekiedy twierdzili, że nie stanowią one „żadnego przeciwieństwa”, lecz są to „dwa zjawiska tego samego rodzaju”, które „nawzajem bez siebie nie są do pomyślenia”25.

Niewątpliwie nacjonalistyczny wydźwięk miało pojęcie rewolucji często używane przez neokonserwatywnych ideologów w Republice Weimarskiej i składające się na nazwę omawianej doktryny. Jako jeden z pierwszych posłużył się nim w połączeniu ze słowem „konserwatyzm” wspomniany Moeller van den Bruck w Das dritte Reich. Przed nim te dwa wykluczające się zresztą pojęcia skojarzyli ze sobą - na zasadzie contradictio in adiecto - Thomas Mann (1921) oraz protestancki polityk i teolog Ernst Troeltsch (1922). Jako „rewolucję konserwatywną” rozumieli oni nie tyle określony program polityczny, ile przede wszystkim problem filozoficzny wyrażający się $\mathrm{w}$ dążeniu do przezwyciężania dualizmu materii i ducha poprzez dokonanie zmian w otaczającej rzeczywistości przy zachowaniu

„Der Vormarsch“ 1929, Heft 11, s. 330; H.U. Klintzsch, Führer und Gefolgschaft, „Der Vormarsch“ 1928, Heft 9, s. 223.

24 Stahlhelm-Handbuch, Hrsg. F. Schauwecker, Magdeburg 1927, s. 50.

25 Por. E. Jünger, Der Arbeiter. Herrschaft und Gestalt, Hamburg 1932, s. 238 i n. (przekład polski: Robotnik. Panowanie i forma bytu. Maksima - minima, Warszawa 2010). W pracy Die totale Mobilmachung (Berlin 1931, s. 21) Jünger pisał: „Sozialismus und Nationalismus die beiden grössen Mühlsteine, zwischen denen der Fortschritt die Reste der alten Welt und endlich sich seibst zermalmt". Por. A. Moeller van den Bruck, Jedes Volk hat seinen eigenen Sozialismus, Oldenburg 1931; O. Spengler, Preussentum und Sozialismus, München 1921. 
pewnych stałych wartości ludzkiej egzystencji ${ }^{26}$. Choć już u tych dwóch myślicieli „rewolucja konserwatywna” oznaczała negację sięgających okresu renesansu i reformacji nowożytnych koncepcji ustrojowo-prawnych i społecznych, to jednak dopiero w ujęciu Moellera van den Brucka stała się ona symbolem doktryny o nacjonalistycznych, antyliberalnych i antymarksistowskich założeniach. Niemal taką samą wymowę ideologiczną miały rozważania innych neokonserwatystów w Republice Weimarskiej nad pojęciem rewolucji konserwatywnej, publikowane już po ukazaniu się Das dritte Reich, m.in. Edgara J. Junga, Hansa Freyera i Hugo von Hofmannsthala. Zespolenie przez wymienionych intelektualistów słów ,konserwatyzm” i ,rewolucja” wynikało z nadania specyficznego znaczenia drugiemu z tych pojęć, zasadniczo różniącego się zwłaszcza od marksistowskiej interpretacji zjawiska rewolucji. Moeller van den Bruck, Jung czy Freyer nie rozpatrywali bowiem rewolucji jako przejawu walki klasowej wyrażającej się w splocie gwałtownych wydarzeń zmierzających do urzeczywistnienia socjalistycznego bądź liberalnego światopoglądu, lecz jej istotę dostrzegali w spontanicznym uzewnętrznieniu się wartości narodowych.

Głoszona przez neokonserwatystów idea rewolucji zawierała się w nacjonalistycznym pojęciu rewolucji niemieckiej skierowanej zarówno przeciwko proletariackiej, jak i mieszczańskiej rewolucji. Nieprzypadkowo zatem wspomniany Troeltsch określił sedno tej koncepcji mianem konserwatywnej kontrrewolucji. Znawca omawianej doktryny, amerykański profesor Klemens von Klemperer, uznał rewolucyjny konserwatyzm za „dziecko” rewolucyjnych wydarzeń w Niemczech w latach 1918-1919, dostrzegając w nim próbę przeciwstawienia się politycznym aspiracjom klasy robotniczej poprzez uwypuklanie potrzeby zapewnienia ,jedności narodu” w warunkach społecznych antagonizmów i zagrożenia Rzeszy ze strony ,zachodnioeuropejskiego imperializmu”27. O swoistej mistyfikacji pojęcia rewolucji przez neokonserwatystów świadczyło utożsamianie istoty tego zjawiska z ,wymarszem narodu”, czyli z jego dążeniem do przekształcenia się w ponadklasową wspólnotę opartą na korporacyjnej strukturze społeczeństwa. Będący rzecznikiem takiej rewolucji E.J. Jung wyobrażał sobie powstanie w jej wyniku nie tylko ,narodowej solidarności” Niemców, lecz także stworzenie w Europie ,nowego porządku, nowego etosu i nowej jedności pod niemieckim przy-

26 T. Mann, Russische Anthologie, [w:] Gesammelte Werke, Bd. 9, Frankfurt am Main 1960, s. 598; idem, Kultur und Sozialismus, [w:] Gesammelte Werke, Bd. 12, Berlin 1965, s. 639 i n.; E. Troeltsch, Der Historismus und seine Probleme, [w:] Gesammelte Schriften, Bd. 1, Tübingen 1922, s. 285; idem, Naturrecht und Humanitdt in der Weltpolitik, [w:] Deutscher Geist und Westeuropa. Gesammelte kulturphilosophische Aufsätze und Reden, Hrsg. H. Baron, Tübingen 1925, s. 14.

${ }^{27}$ K. von Klemperer, Germany's New Conservatism: Its History and Dilemma in the Twentieth Century, New Jersey 1968, s. 75. Por. A. Mohler, Die konservative Revolution in Deutschland. Grundriss ihrer Weltanschauung, Stuttgart 1950, s. 18 i n.; O.E. Schüddekopf, Linke Leute von rechts. Die nationalrevolutionären Minderheiten und der Kommunismus in der Weimarer Republik, Stuttgart 1960, s. 150 i n. 
wództwem"28. Rewolucja o konserwatywnych i narodowych cechach oznaczała zatem dla niego metodę przywrócenia mocarstwowej pozycji Rzeszy w stosunkach międzynarodowych. Również wspomniany Hofmannsthal, austriacki pisarz i poeta, ujmował w kategoriach narodowych istotę „rewolucji konserwatywnej”. W opublikowanej w 1927 r. rozprawie filozoficzno-literackiej Das Schrifttum ais geistiger Raum der Nation dowodził, że ukształtowanie się ,,prawdziwego narodu" w Niemczech będzie w warunkach powszechnego po I wojnie światowej „kryzysu cywilizacji” zależeć od „restauracji tradycji”, która powinna zapewnić ponowne zespolenie się wszystkich członków społeczeństwa poprzez podporządkowanie indywidualnej wolności potrzebom zbiorowości. Proces zmierzający do osiągnięcia tego celu określił jako „rewolucję konserwatywną” o dotąd „nieznanym zasięgu”. Upatrując w niej „,wewnętrznego antyruchu” i „produktywnej anarchii” wymierzonej w humanistyczną filozofię odrodzenia i późniejsze postępowe nurty europejskiej kultury umysłowej, Hofmannsthal przewidywał powstanie w wyniku tej rewolucji „,nowej niemieckiej rzeczywistości”, w której „mógłby uczestniczyć cały naród" 29 . Austriackiemu myślicielowi bynajmniej nie chodziło o poszerzenie form demokracji, uważanej zresztą przez niego za jedną z przyczyn kryzysu cywilizacji na początku XX w., lecz o stworzenie przesłanek dla duchowej jedności Niemców jako warunku przekształcenia się w narodową wspólnotę.

Bardziej nacjonalistycznie niż Hofmannsthal ,rewolucję konserwatywną” postrzegał Moeller van den Bruck. Już w zaproponowanej przez niego definicji rewolucjonisty zawierały się elementy nacjonalistycznego światopoglądu. Dla autora Das dritte Reich rewolucjonistą był ten, kto w „,swym odczuciu, w swej więzi duchowej i w swej przynależności do losu” mógł zostać uznany za członka „niemieckiego plemienia" (deutsches Geschlecht) ${ }^{30}$. W ocenie Moellera van den Brucka na miano takie nie zasługiwali uczestnicy proletariackiej rewolucji w Niemczech w latach 1918-1919. W rewolucji tej dostrzegał jedynie „rewoltę” zasadniczo różniącą się z tego względu od „konserwatywnej rewolucji niemieckiej”, określanej przez tego neokonserwatystę również jako „narodowe powstanie" ${ }^{31}$. Dla Junga rewolucja listopadowa w Rzeszy, przeprowadzona przez komunistów, stanowiła „buntowniczą rewolucję" przeciwników ustroju monarchistycznego, których działalność porównywał do politycznej aktywności wrogów dynastii Bourbonów podczas rewolucji we

28 E.J. Jung, Deutschland und die konservative Revolution, [w:] Deutsche über Deutschland. Die Stimme des unbekannten Politikers, München 1931, s. 380.

29 H. von Hofmannsthal, Das Schrifttum als geistiger Raum der Nation, München 1921, s. 31. Por. H. Rudolph, Kulturkritik und der konservativen Revolution. Zum kulturell-politischen Denken Hofmannsthals und seinem problemgeschichtlichen Kontext, Tübingen 1971, s. 117, 123, 169 i n.; R. Faber, Roma aeterna. Zur Kritik der „,Konservativen Revolution“, Würzburg 1981, s. 82-84.

30 A. Moeller van den Bruck, Das dritte..., s. 9.

31 Por. H. Hansen, Die ungelöste Revolution, „Standarte“ 1927, Heft 1, s. 18-21; D. Schafer, Die werden wir ein Volk? Wie konnen wir es bleiben?, München 1919, s. 72; A. Winnig, Wir hütten das Feuer. Aufsätze und Reden aus zehn Jahren (1923-1933), Hamburg 1933, s. 15. 
Francji pod koniec XVIII w. Na paralele między tymi dwiema rewolucjami zwracał uwagę również autor głośnego po I wojnie światowej dzieła historiozoficznego Der Untergang des Abendlandes - Oswald Spengler ${ }^{32}$. Do ideologicznego dorobku rewolucji francuskiej niezmiernie krytycznie odnosili się wszyscy rewolucyjni konserwatyści niemieccy, nadając głoszonej przez siebie koncepcji rewolucji znaczenie ,antyrewolucji” wobec ,zasad roku 1789”. Pod tym względem w ogóle nie różnili się oni od przedstawicieli tradycyjnego konserwatyzmu w XIX w., a nawet bywali od nich jeszcze bardziej nieprzejednani w negacji liberalizmu jako jednego z głównych elementów doktryny rewolucji mieszczańskiej ${ }^{33}$. Na przykład Moeller van den Bruck dowodził, że liberalizm ,,zaprzepaszcza narody”, ponieważ oznacza „pogrzebanie” kultury, „zniweczenie” religii, ,zniszczenie” poczucia patriotyzmu itp. Dla wspomnianego Freyera oraz m.in. dla profesora prawa państwowego Carla Schmitta liberalizm stanowił w warunkach społeczno-politycznego kryzysu po I wojnie światowej przeżytek etosu mieszczańskich wartości z zasadą suwerenności ludu na czele ${ }^{34}$. Zarówno liberalnym, jak i socjalistycznym koncepcjom politycznym Freyer przeciwstawiał na początku lat 30. XX w. ideę nacjonalistycznej ,rewolucji z prawa" (Revolution von rechts), która miała się od dotychczasowych rewolucji różnić tym, że ,zwraca się ku człowiekowi”, nie zaś ku ,abstrakcyjnej” zbiorowości ludzkiej. Freyer usiłował wykazać, że w zapowiadanej przez niego rewolucji każda jednostka odnajdzie - inaczej niż w „rewolucjach z wczoraj” - swoje miejsce „w historycznym froncie narodu” ${ }^{35}$. Od „zmartwychwstania” narodu miała rozpocząć się ,rewolucja” w ujęciu Moellera van den Brucka. Jeszcze inny neokonserwatysta w Republice Weimarskiej, Eduard Stadtler, wprowadził do nacjonalistycznego słownictwa politycznego w tym okresie pojęcie „światowa rewolucja wojenna" (Weltkriegsrevolution), o jednocześnie antyproletariackim i antyburżuazyjnym wydźwięku. Upatrywał w niej przesłanki uformowania siłą ,państwa społecznego”, „wspólnej gospodarki” i ,wspólnoty światowej”, bliżej nie wyjaśniając jednak istoty oczekiwanych przemian w stosunkach wewnętrznych i międzynarodowych ${ }^{36}$.

32 O. Spengler, Briefe 1913-1936, Hrsg. A.M. Koktanek, München 1963, s. 112.

33 Na przykład Jung pisał w Sinndeutung der deutschen Revolution (Oldenburg 1933, s. 43): „Die deutsche konservative Revolution kann ihren Charakter ais Gegenrevolution nur bewahren in der Abkehr von den geistigen Gesetzen, welche die liberale Revolution von 1789 beherrschten “. Por. F. von Papen, Appel an das deutschen Gewissen. Reden zur nationalen Revolution, Oldenburg 1933, s. $100 \mathrm{i}$.

34 Do najbardziej dojrzałych pod względem teoretycznym argumentów przeciwko liberalizmowi należała rozprawa Carla Schmitta Die geistesgeschichtliche Lage des heutigen Parlamentarismus (München-Leipzig 1923).

35 H. Freyer, Revolution von rechts, Jena 1931, s. 71.

36 Poglądy na ten temat wyłożył w pracy Die Weltkriegsrevolution (Leipzig 1920), nawiązującej do wydanej rok wcześniej w Berlinie pracy Weltkrieg, Welttragödie und Weltbolschewismus. Por. R. Stutz, Die politische Entwicklung Eduard Stadtlers von 1918 bis 1933. Ein Beitrag zur Geschichte des Rechtsextremismus in der Weimarer Republik, Jena 1985, s. 42; J. Petzold, 
Nie ulega wątpliwości, że oznaczałyby one polityczną i ekonomiczną hegemonię Niemiec w Europie. Rewolucyjni konserwatyści nie kryli się zresztą z takimi zamiarami. Na przykład publicyści skupieni wokół czasopisma „Die Tat” propagowali ideę środkowoeuropejskiej federacji (Mitteleuropa) pod przywództwem Rzeszy, obejmującej Austrię, Czechosłowację, Węgry, Rumunię, Polskę i kraje bałtyckie ${ }^{37}$.

Z ekspansjonistycznymi celami doktryny neokonserwatywnej wiązał się rozpowszechniany przez nią kult wojny, nawiązujący do idei roku 1914 oraz wyrażający apoteozę siły i nietzscheańskiej „woli mocy”. Podobnie jak inne elementy rewolucyjno-konserwatywnej ideologii wojna była ujmowana metafizycznie. Tak jak na początku I wojny światowej stanowiła ona rodzaj wyznania wiary, zawierającego w sobie ponadludzki, niemal boski pierwiastek. O ile w 1914 r. takie ujmowanie wojny służyło interesom cesarstwa Hohenzollernów, umacniając jego potęgę, o tyle apoteoza wojny przez rewolucyjnych konserwatystów kryła w sobie zagrożenie dla osłabionego wewnętrznymi konfliktami państwa niemieckiego po 1918 r. Według słów intelektualisty Waltera Benjamina wojenne resentymenty tych intelektualistów czy nazistów stanowiły „symptom chłopięcego rozmarzenia", które mogło przekształcić się we frontalny atak na Republikę Weimarską, uważaną przez rozmaite siły nacjonalistyczne w ówczesnej Rzeszy za jeden z przejawów „ciosu nożem w plecy” zadanego Niemcom pod koniec I wojny światowej. Neokonserwatywna teoria wojny miała - jak twierdził w 1930 r. Benjamin - „na czole wypisane pochodzenie od najbardziej bezwzględnego dekadentyzmu"38. Przedstawiciele tej doktryny chętnie odwoływali się do tezy Heraklita z Efezu, że wojna jest „ojcem wszystkich rzeczy”. W kwestii stosunku do wojny inspirowały rewolucyjnych konserwatystów również poglądy Georga Wilhelma Friedricha Hegla. Uwypuklając rzekomo konstruktywną rolę wojny, dostrzegali w niej jedną z podstawowych zasad życia, moralności, funkcjonowania państwa, a przede wszystkim rozwoju narodu ${ }^{39}$. Wojna uchodziła w neokonserwatywnej doktrynie

Konservative Theoretiker des deutschen Faschismus. Jungkonservative Ideologen in der Weimarer Republik ais geistige Wegbereiter der faschistischen Diktalur, Berlin 1978, s. 37 i n.

37 Por. H. Hecker, ,Die Tat “ und ihr Osteuropabild 1909-1939, Koln 1974, passim; K. Fritzsche, Politische Romantik und Gegenrevolution. Fluchtwege in der Krise der bürgerlichen Gesellschaft: das Beispiel des ,,Tat"-Kreises, Frankfurt am Main 1976, s. 216-218.

38 W. Benjamin, Teorie niemieckiego faszyzmu. O pracy zbiorowej pt. Wojna i wojujacy, pod redakcja Ernsta Jüngera, [w:] Walter Benjamin, Gottfried Benn, Ernst Bloch, Bertolt Brecht, Hermann Broch, Elias Canetti, Max Horkheimer, Theodor W. Adorno, Victor Klemperer, Siegfried Krackauer, Karl Kraus, Heinrich Mann, Klaus Mann, Thomas Mann, Joseph Roth, Friedrich Wolf wobec faszyzmu, wyb. i wstęp H. Orłowski, Warszawa 1987, s. 26.

39 K. Sontheimer, Antidemokratisches Denken..., s. 116 i n.; K. Prümm, Die Literatur des soldatischen Nationalismus der 20er Jahre (1918-1933). Gruppenideologie und Epochenproblematik, Bd. 1, Kronberg Taunus 1974, s. 41 i n.; E. Momber, 's ist Krieg! 's ist Krieg! Versuch zur Literatur über den Krieg 1914-1933, Berlin 1981, s. 92 i n.; H.-J. Mauch, Nationalistische Wehrorganisationen in der Weimarer Republik. Zur Entwicklung und Ideologie des ,, Paramilitarismus “, Frankfurt am Main 1982, s. 97 i n.; J. Miziński, Filozofia wojny w literaturze nacjonalizmu żotnierskiego ze szczególnym 
- jak wcześniej w ideach roku 1914 - za rodzaj sztuki uprawianej dla samego jej „artyzmu” i mającej dostarczać wzniosłych przeżyć estetycznych. W opinii Spenglera wojna była ,prapolityką wszystkiego, co żyje, aż do tego stopnia, że walka i życie są w najgłębszej istocie tym samym, a wraz z wygaśnięciem woli walki zamiera istnienie" ${ }^{40}$. Do poglądu autora Der Untergang des Abendlandes nawiązał w 1927 r. Carl Schmitt, uznając w rozprawie Der Begriff des Politischen wojnę za „odwieczną formę ludzkiego bytu” oraz za „punkt kulminacyjny wielkiej polityki”. Według Manna w wojnie miał być „zawarty mistyczny element” spajający w jedną całość „,wszystkie podstawowe siły życia i śmierci, religii i miłości”41. E. Jünger przekonywał w Der Kampf als innere Erlebnis (1922), że wojna stanowi „napór życia”, ono zaś znaczy tyle samo, co „zabijać”. Ponieważ bez walki nie można sobie wyobrazić życia - twierdził ten rewolucyjny konserwatysta - wobec tego nie jest istotne, „o co walczymy”, lecz ,jak walczymy”. E. Jünger określał wojnę również jako „czynnik przewartościowujący wartości”, przede wszystkim w sferze spraw narodowych ${ }^{42}$.

Ujmowana w kategoriach nacjonalistycznych wojna była dla neokonserwatywnych ideologów w Republice Weimarskiej przesłanką kształtowania się heroicznej osobowości, cechującej zwłaszcza żołnierzy frontowych (Frontsoldaten). Zamiennie określano tę grupę społeczną mianem wojowników (Kämpfer, Krieger), obejmując nim także tych, którzy nie uczestniczyli bezpośrednio w działaniach militarnych, lecz tylko pośrednio angażowali się w wojnę na „różnych frontach walki i pracy”. W „wojownikach” rewolucyjni konserwatyści upatrywali współtwórców wartości wyższego rzędu zrodzonych na polach bitew (koleżeństwo, braterstwo, poświęcenie, obowiązek, honor itp.), które powinny być utrwalane w życiu cywilnym dla dobra „wspólnoty narodowej”. Źródeł przeobrażeń zachodzących w osobowości zarówno żołnierzy frontowych, jak i innych grup społecznych doszukiwała się omawiana doktryna w emanacji na psychikę ,przeżycia wojennego" (Kriegserlebnis ${ }^{43}$. E. Jünger we wstępie do powołanej już pra-

uwzględnieniem twórczości Ernsta Jüngera, „Kultura i Społeczeństwo” 1978, nr 4; H. Orłowski, Pierwsza wojna światowa w literaturze niemieckiej lat 1919-1933, „Przegląd Zachodni” 1968, nr 4.

40 O. Spengler, Der Untergang des Abendlandes. Umrisse einer Morphologie der Weltgeschichte, Bd. 2, München 1922, s. 550. Por. F.G. Jünger, Krieg und Krieger, Hrsg. E. Jünger, Berlin 1930, s. 60; E. Jünger, Der Kampf als innere Erlebnis, Berlin 1922, s. 2; W. Heinz, Die Nation greift an: Geschichte und Kritik des soldatischen Nationalismus, Berlin 1933, s. 17.

41 T. Mann, Betrachtungen eines Unpolitischen, Berlin 1918, s. 471.

42 Der Kampf um das Reich, Hrsg. E. Jünger, Essen 1929, s. 6. Niektóre teksty tego autora z tamtego okresu doczekały się polskiego wydania. Zob. m.in. E. Jünger, Publicystyka polityczna 1919-1936, Kraków 2007.

43 Por. m.in. E.J. Jung, Die Herrschaft der Minderwertigen. Ihr Zerfall und ihre Ablösung durch ein Neues Reich, Berlin 1930, s. 17; K.S. Galera, Das junge Deutschland und das Dritte Reich, Leipzig 1932, s. 40; E.G. Gründel, Die Sendung der Jungen Generation. Versuch einer umfassenden revolutionären Sinndeutung der Krise, München 1933, s. 329; A. Mahraun, Das Jung- 
cy Aufmarsch des Nationalismus uznał wojnę za „przeżycie krwi”, stanowiące nie tylko oznakę wspólnoty biologicznej, lecz także duchowej więzi uczestników działań militarnych, która wynikała z poczucia przynależności do tego samego narodu. Podkreślając służebną rolę wojny wobec interesów narodowych, tak pisał w In Stahlgewittern (1920) o obowiązkach żołnierza: „Wiesz, że postawiono cię w tym miejscu, żebyś walczył i cały naród ufa, iż zrobisz, co do ciebie nale$\dot{z} y^{\prime \prime 4}$. W neokonserwatywnej literaturze politycznej i utworach literackich utarło się przeświadczenie, że prawdziwy Niemiec to „dobry żołnierz”, gotowy oddać swe życie za ojczyznę. Poczucie żołnierskiej jedności i poświęcenia dla narodu miało różnić osobowość ,wojownika” od psychiki odznaczającego się egoizmem „mieszczanina" 45 . Przeciwstawiając te dwa typy osobowości, E. Jünger nakreślił w rozprawie Der Arbeiter. Herrschaft und Gestalt (1932) wizerunek „nowej rasy człowieka”, który łączył w sobie zarówno cechy żołnierza, jak i robotnika. Z ukształtowaniem się tej warstwy wiązał nadzieję na „nastanie nowych Niemiec”, opartych nie na rasowej czystości tego narodu, lecz na jego totalnej mobilizacji dla ojczyzny ${ }^{46}$. Jedną z głównych przesłanek funkcjonowania państwa „robotniko-żołnierzy”, niemającego zresztą nic wspólnego z dyktaturą proletariatu, dostrzegał w rozwoju techniki. Kult dla wynalazków różnił E. Jüngera od niektórych innych przedstawicieli doktryny neokonserwatywnej (m.in. Spenglera), przyjmujących na ogół antymodernistyczną postawę wobec osiągnięć cywilizacji technicznej, traktowanych przez nich jako przejaw „mechanizacji” stosunków społecznych ${ }^{47}$. Oparty na nacjonalistycznych i solidarystycznych założeniach ideał państwa „robotniko-żołnierzy” wyrażał „heroiczny realizm” światopoglądu E. Jüngera. W literaturze o tym rewolucyjnym konserwatyście bywa on określany również mianem aktywnego nihilizmu ${ }^{48}$.

deutshe Manifest. Volk gegen Kaste und Geld. Sicherung des Friedens durch Neubau der Staaten, Berlin 1928, s. 8; F. Schauwecker, Verwandlung der Seele, [w:] Aufstand. Querschnitt durch den revolutionären Nationalismus, Hrsg. G.O. Stoffregen, Berlin 1931, s. 24 i n.

44 E. Jünger, In Stahlgewittern. Aus dem Tagebuch eines Stosstruppführers, Berlin 1942, s. 137. Por. F. Schauwecker, Der Aufbruch der Nation aus dem Kriege, [w:] Deutscher Aufstand. Die Revolution des Nachkriegs, Hrsg. C. Hotzel, Stuttgart 1934, s. 247.

45 Por. E. Jünger, Der Arbeiter ..., s. 37; idem, Die Kriegsschuld des Bürgers, „Die Sozialistische Nation“"1932, Heft 8/9 (September), s. 3.

46 Idem, Der Arbeiter..., s. 25.

47 Por. np. pogląd Spenglera (Der Untergang des Abendlandes..., s. 526) zmodyfikowany nieco w pracy Der Mensch und die Technik (München 1933, s. 7, 14), a także opinię F.G. Jüngera wyrażoną w rozprawie Die Perfektion der Technik (Frankfurt am Main 1949, s. 38).

48 Por. V. Droste, Ernst Jünger: „Der Arbeiter“. Studien zu seiner Metaphysik, Mainz 1980, s. 68; G. Loose, Ernst Jünger. Gestalt und Werk, Frankfurt am Main 1957, s. 103; W. Sonn, Der Mensch im Arbeitszeitalter. Das Werk E. Jüngers als Auseinandersetzung mit dem Nihilismus, Saarbrücken 1971, s. 71-72; S. Bein, Der Arbeiter. Typus - Name - Gestalt, [w:] Wandlung und Wiederkehr. Festsschrift zum 70. Geburtstag Ernst Jüngers, Hrsg. H.L. Arnold, Aachen 1965, s. 110-111. 
Neokonserwatyści po 1918 r. uważali się za spadkobierców wciąż żywych w licznych kręgach niemieckiego społeczeństwa militarystycznych tradycji z okresu I wojny światowej. Odwołując się znów do opinii E. Jüngera, można przytoczyć jego wypowiedź charakteryzującą postawę całej generacji frontowej, że wojna „porwała nas i oszołomiła”. Wśród jej uczestników żyła bowiem - jak pisał w In Stahlgewittern - „tajemna tęsknota za rzeczami niezwykłymi”. Wojna lat 1914-1918 wydawała się temu rewolucyjnemu konserwatyście „męskim czynem, radosnym bojem strzeleckim na kwiecistej, krwią zroszonej łące”. Neokonserwatywny ideolog Karl Anton Rohan twierdził w 1930 r., że dzięki wojnie światowej „staliśmy się sobą” i dlatego „powinniśmy każdą myśl zaczynać wspomnieniami wojennych przeżyć" ${ }^{49}$. Nawiązujący do etosu minionych działań militarnych w Europie Franz Schauwecker pragnął dowieść: „Musieliśmy przegrać wojnę, aby wygrać naród”. Do rangi politycznego symbolu jedności i prężności narodu niemieckiego w momencie wybuchu I wojny światowej urosły popularne wtedy idee roku 1914, utrwalane przez rewolucyjnych konserwatystów i inne siły nacjonalistyczne w okresie Republiki Weimarskiej. Dla jednego z reprezentantów tej koncepcji, Johanna Plenge, data rozpoczęcia konfliktu militarnego między państwami centralnymi a Ententą oznaczała pierwszą w dziejach Niemiec próbę urzeczywistnienia zasad „społeczeństwa socjalistycznego" opartych na sprawnej organizacji życia gospodarczego i politycznego. Plenge przeciwstawiał - podobnie jak inni neokonserwatyści - idee roku 1914 doktrynie rewolucji francuskiej z przełomu XVIII i XIX w. ${ }^{50}$ Witający z uznaniem wybuch I wojny światowej Mann dowodził, że jeśli Niemcy w niej zwyciężą, to sukces militarny Rzeszy będzie stanowić zwycięstwo „niemieckiego ducha” nad „pacyfistyczną ideą cywilizacji”. Celu rozpoczętych w sierpniu 1914 r. działań militarnych w Europie upatrywał w ustanowieniu „niemieckiego pokoju", czyli w kulturalnej i politycznej hegemonii Rzeszy na tym kontynencie. Z udziałem Niemiec w wojnie światowej wiązał nadzieję na „rzeczywistą syntezę władzy i ducha" w mającej powstać po zakończeniu działań militarnych „trzeciej Rzeszy"51. Podobnie ujmował genezę przyszłego państwa niemieckiego Moeller van den Bruck, choć jego koncepcja „trzeciej Rzeszy” zrodziła się już po 1918 r., stanowiąc przede wszystkim antytezę Republiki Weimarskiej.

49 Za: K. Sontheimer, Antidemokratisches Denken..., s. 116. Por. W. Wirths, Das Erlebnis des Krieges, [w:] Die Neue Front, Hrsg. A. Moeller van den Bruck, H. von Gleichen, M.H. Boehm, Berlin 1922, s. 76.

50 J. Plenge, 1789 und 1914. Die symbolischen Jahren in der Geschichte des politischen Geistes, Berlin 1916. Inny rzecznik wojennego etosu, Werner Sombart (Händler Und Helden. Patriotische Besinnungen, München-Leipzig 1915), dostrzegał w wojnie starcie angielskich „,handlarzy” z niemieckimi „bohaterami”, a filozof Max Scheler (Der Genius des Krieges und der Deutsche Krieg, Leipzig 1915) podkreślał rolę wojny w tworzeniu narodowej jedności Niemców.

51 T. Mann, Friedrich und die grosse Koalition, Berlin 1916, s. 126. 
Przeciwieństwem parlamentarno-demokratycznych rządów w Niemczech po I wojnie światowej była głoszona przez niektórych przedstawicieli ówczesnych środowisk kombatanckich idea „,państwa żołnierzy frontowych”. Potrzebę jego ustanowienia uzasadniano w paramilitarnej ideologii nacjonalistycznej obowiązkiem „narodowej wdzięczności” za męstwo i poświęcenie byłych uczestników I wojny światowej ${ }^{52}$. W dawnych żołnierzach frontowych Jung dostrzegał „nosicieli nowego losu Niemiec”, a Schauwecker utrzymywał, że stanowią oni „twardą jak skała opokę naszej lepszej i piękniejszej przyszłości”. Jeszcze większe nadzieje na narodowe odrodzenie się Niemiec po I wojnie światowej pokładali rewolucyjni konserwatyści w młodzieży. Na przykład Rohan dowodził w pracy Die Aufgabe unserer Generation (1926), że młodzież z natury jest rewolucyjna. Pragnąc zmian, tworzy „nowe poczucie życia”, które określił mianem rewolucji konserwatywnej ${ }^{53}$. Analogicznie wypowiadał się o zadaniach młodzieży niemieckiej Ernst Günther Gründel w publikacji Die Sendung der Jungen Generation (1933). Niedługo po zakończeniu I wojny światowej Spengler apelował do młodzieży, by miała „odwagę i zimną krew” i mogła „wydać z siebie prawdziwych mężczyzn" ${ }^{54}$. Nietrudno zauważyć, że apoteoza wojny światowej przez rewolucyjnych konserwatystów wyrażała tęsknotę za utraconą w jej wyniku wielkością i potęgą Rzeszy wilhelmińskiej. Poprzez propagowanie kultu wojny z roku 1914 starali się oni niejako zaklinać absolutnie nieuznawaną przez nich - o czym już wzmiankowałem - powojenną rzeczywistość.

Odwoływanie się przez rewolucyjnych konserwatystów do nacjonalistycznego etosu wojny światowej służyło przedstawicielom omawianej doktryny za przesłankę krytyki dziejów Niemiec po 1918 r. W neokonserwatywnej literaturze politycznej i historiografii upowszechniła się teza o „zawieszeniu” historii Rzeszy między okresem cesarstwa Hohenzollernów a przyszłym państwem niemieckim, mającym powstać po rozpadzie systemu rządów demokracji parlamentarnej. Negatywnie oceniający zarówno dorobek wilhelmińskiej Rzeszy, jak i Republiki Weimarskiej Moeller van den Bruck rozważał w związku z tym problem ,międzyhistorii” (Zwischengeschichte) Niemiec po I wojnie światowej, a Spengler twierdził: „Żyjemy dzisiaj między czasami”"55. Publicyście wspomnianego „Die Tat”, Ferdinandowi Friedowi, powojenne dzieje Rzeszy przypominały burzliwe wyda-

52 Por. A. Klotzbücher, Der politische Weg des Stahlhelms, Bund der Frontsoldaten, in der Weimarer Republik. Ein Beitrag zur Geschichte des ,Nationalen Opposition“ 1918-1933, Erlangen 1965, s. 121 i n.

53 K.A. Rohan, Die Aufgabe unserer Generation, Köln 1926, s. 20.

54 O. Spengler, Preussentum..., s. 98. W 1922 r. z apelem do niemieckiej młodzieży o zaangażowanie się w „sprawy narodu” zwrócili się wydawcy powołanej tu pracy zbiorowej Die Neue Front. Por. także artykuł Das Erbe opublikowany w organie młodokonserwatystów „Gewissen” 7 VI 1921.

55 O. Spengler, Jahre der Entscheidung. Deutschland und die weltgeschichtliche Entwicklung, Bd. 1, München 1933, s. 17. 
rzenia w okresie francuskiej rewolucji mieszczańskiej końca XVIII w. Freyerowi zaś ówczesny etap historii Niemiec kojarzył się z „progiem czasu” (Schwellenzeit) oznaczającym „wyczekiwanie" na nową rzeczywistość polityczną ${ }^{56}$. Z kolei Troeltsch pisał w 1924 r. o Rzeszy jako „krainie marzeń okresu zawieszenia broni”, w którym każdy mógł „fantastycznie, pesymistycznie lub heroicznie odmalować przyszłość". Pogląd tego ideologa odzwierciedlał wielość społecznych oczekiwań i narodowych pragnień w Niemczech po I wojnie światowej ${ }^{57}$. Traktując Republikę Weimarską jako okres „antyhistorii” niemieckiej, neokonserwatyści uważali ówczesną Rzeszę za swego rodzaju nowotwór polityczny, od którego usunięcia uzależniali dalsze istnienie i rozwój swego narodu. Nacjonalistyczny pisarz i publicysta Ernst Niekisch w ogóle odmawiał Republice Weimarskiej miana państwa (Unstaat), gdyż powojenne rządy niemieckie miała cechować „całkowita bezsilność polityczna i narodowa"58. Rzesza po 1918 r. uchodziła w rewolucyjno-konserwatywnej doktrynie za „karykaturę państwa” (W. Gerhart), „pozorne państwo” (F.G. Jünger) lub „formalne państwo” (W. Stapel). Reprezentujący ideologię wspomnianego Stahlhelmu Wilhelm Kleinau porównywał Republikę Weimarską do „wypadku przy pracy” (Betriebsunfall) w dziejach niemieckiej państwowości ${ }^{59}$. Dla katolickiego historyka i pisarza politycznego o konserwatywnych zapatrywaniach Martina Spahna była ona jedynie „przejściowym stanem” w historii Niemiec, ,skazanych" na demokrację parlamentarną" tylko do czasu powstania „państwa chrześcijańskiego” jako syntezy dziejów Rzeszy ${ }^{60}$. Również Jung wyobrażał sobie, że ukoronowaniem historycznego rozwoju Niemiec będzie - po likwidacji demokracji parlamentarnej - ustanowienie „Rzeszy Boga na ziemi”. W religijnych kategoriach rozpatrywali swe idee przyszłej Rzeszy niektórzy inni rewolucyjni konserwatyści, m.in. Friedrich Hielscher i Wilhelm Stapel. Wszystkie neokonserwatywne wizje „prawdziwego" państwa niemieckiego opierały się na przesłankach „nowego nacjonalizmu”, łączących się z zupełną negacją

56 M.T. Greven, Konservative Kultur-und Zwilisationskritik in „Dialektik der Aufklärung“ und ,Schwelle der Zeiten “, [w:] Konsenatismus - eine Gefahr fur die Freiheit?, Hrsg. E. Henning, R. Saage, München-Zürich 1983, s. 148-149. E. Niekisch (Entscheidung, Berlin 1930, s. 185) określił swą generację jako ,pokolenie zwrotnego momentu w dziejach świata".

57 Por. E. Troeltsch, Spektatorbriefe. Aufsätze über die Revolution und die Weltpolitik 1918-1922, Tübingen 1924, s. 69; W. Bussmanh, Politische Ideologien zwischen Monarchie und Weima er Republik. Ein Beitrag zur Ideengeschichte der Weimarer Republik, „Historische Zeitschrift“ 1960, Bd. 190, s. 56.

58 U. Sauermann, Ernst Niekisch. Zwischen allen Fronten, München-Berlin 1980, s. 114. Por. F. Kabermann, Widerstand und Entscheidung eines deutschen Revolutionars. Leben und Denken von Ernst Niekisch, Köln 1973, s. 50-51; H. Buchheim, Ernst Niekischs Ideologie des Widerstandes, „Vierteljahrshefte fur Zeitgeschichte“ 1957, Heft 4, s. 361 i n.

59 W. Kleinau, Stahlhelm und Staat, Berlin 1929, s. 60.

60 G. Clemens, Martin Spahn und der Rechtskatholizismus in der Weimarer Republik, Mainz 1983, s. 76. Szerzej o stosunku historyków niemieckich do demokracji parlamentarnej po 1918 r. por. H. Olszewski, Nauka historii w upadku. Studium o historiografii i ideologii historycznej w imperialistycznych Niemczech, Warszawa-Poznań 1982, s. 155-156 i n. 
liberalizmu politycznego i przynajmniej częściowym odrzuceniem liberalizmu gospodarczego ${ }^{61}$.

Z tego względu niemal każdy rewolucyjny konserwatysta krytykujący Republikę Weimarską zarzucał jej rządom „nienarodowy” charakter. W przekonaniu Spenglera ustrój Rzeszy po 1918 r. przypominał działalność „firmy” opanowanej przez „szalejące partie polityczne” i przekształconej w „kolonię” spłacającą odszkodowania wojenne byłym państwom Ententy (Reparationskolonie) ${ }^{62}$. Dla Junga Republika Weimarska była - o czym pisał w artykule Revolutionäre Staatsführung (1932) - „państwem handlarzy” niemieckich interesów narodowych. Za „wyrobnicę" traktatu wersalskiego z 1919 r. uchodziła ona w ocenie Moellera van den Brucka, który republikańskie rządy Rzeszy określał zawsze tylko pejoratywnie: „kameleon”, „moloch”, „Lewiatan w swej połyskującej okropności”63. Krytyka Republiki Weimarskiej bynajmniej nie dla wszystkich rewolucyjnych konserwatystów oznaczała aprobatę dla ustroju monarchicznego. Zarówno zwolennicy, jak i przeciwnicy tego ustroju wśród neokonserwatystów zgodnie jednak twierdzili, że tylko silne państwo może służyć interesom narodowym. Tego powszechnego $\mathrm{w}$ omawianej doktrynie przekonania nie podważył toczący się w niej na przełomie lat 20. i 30. spór autorytarny bądź totalitarny model władzy państwowej ${ }^{64}$. Podobnie jak w ideologii tradycyjnego konserwatyzmu dziewiętnastowiecznego, tak i w myśli politycznej rewolucyjnych konserwatystów państwo uchodziło za najwyższą formę organizacji społeczeństwa. Uwypuklanie roli państwa przez omawianą doktrynę nie oznaczało wszakże jego prymatu nad narodem, lecz dążenie do identyfikacji obu pojęć. W celu konsolidacji narodu i państwa F.G. Jünger postulował w 1926 r. „,nacjonalizację państwa i upaństwowienie narodu". Mniej więcej w tym samym czasie propaganda nacjonalistycznej organizacji Jungdeutscher Orden głosiła: „My jesteśmy państwem, my wszyscy Niemcy, my naród" ${ }^{65}$. Wypowiadając się za ustanowieniem w Rzeszy państwa narodowego (Volksstaat), rewolucyjni konserwatyści formułowali koncepcję wspólnoty narodowej, która stała się „idolem” również innych antydemokratycznych sił reakcji w Republice Weimarskiej. Przesiąkniętą mistycyzmem koncepcję Volks-

${ }^{61}$ Na temat wariantów koncepcji Rzeszy w nacjonalistycznej ideologii niemieckiej po I wojnie światowej por. m.in. K. Sontheimer, Die Idee des Reiches im polityschen Denken der Weimarer Republik, „Geschichte in Wissenschaft und Unterricht“" 1962, Heft 4, s. 206 i n.

62 O. Spengler, Neubau des Deutschen Reiches, München 1924, s. 9, 14.

${ }^{63}$ Szerzej piszę o tym w artykule Koncepcja Trzeciej Rzeszy Arthura Moellera van den Brucka, „Studia nad Faszyzmem i Zbrodniami Hitlerowskimi” 1980, t. 6, s. 60 i n. Odsyłam też do monografii H.-J. Schwierskotta Arthur Moeller van den Bruck und der revolutionären Nationalismus in der Weimarer Republik (Göttingen 1962).

${ }^{64}$ Rozróżnienie tych dwóch modeli władzy stało się przedmiotem ożywionej dyskusji na łamach neokonserwatywnego pisma „Der Ring” z 1931 r., m.in. z udziałem C. Schmitta i H. Grünberga.

65 Za: E. Maste, Die Republik der Nachbarn. Die Nachbarschaft und der Staatsgedanke Arthur Mahrauns, Giessen 1957, s. 107. 
gemeinschaft przeciwstawiano często - sięgając do teorii socjologa Ferdinanda Tönniesa - pojęciu społeczeństwa, upatrując w nim „mechaniczny i sztuczny wytwór" sumy jednostek pozostających ze sobą w luźnym związku. W odróżnieniu od zatomizowanego społeczeństwa wspólnota narodowa miała się opierać na naturalnych więzach krwi, ducha i sąsiedztwa ${ }^{66}$. Neokonserwatywna doktryna na ogół nie uwypuklała - poza tzw. yolkistowskim jej odłamem - rasowego charakteru Volksgemeinschaft. Co prawda, elementy rasizmu zawierała opracowana jeszcze w okresie Republiki Weimarskiej Maxa Hildeberta Boehma koncepcja „samodzielnego narodu” (eigenständiges Volk), lecz ten rewolucyjny konserwatysta nie podniósł rasy do roli najważniejszego czynnika narodowotwórczego, choć silniej niż inni przedstawiciele omawianej ideologii akcentował biologiczne aspekty $V_{0} l k u^{67}$. Również teoria narodowości Wilhelma Stapela sprzed $1933 \mathrm{r}$. opierała się na pewnych elementach rasizmu. Były one jednak traktowane przez niego tak samo, jak pozostałe składniki tzw. nomos, czyli „prawa życia” narodu, objawiającego się zwłaszcza w chrześcijańskim charakterze Niemców ${ }^{68}$. Stapel sprzeciwiał się ujmowaniu kwestii rasowych jako „dogmatu” egzystencji narodu, choć dostrzegał zagrożenie dla Niemców ze strony Żydów.

Należy zauważyć, że antysemityzm nie stanowił wyróżnika ideologii neokonserwatywnej, a zwłaszcza jej młodokonserwatywnego odłamu. Reprezentujący ten nurt „rewolucji konserwatywnej” Moeller van den Bruck sceptycznie odnosił się do problemu „germańskości” Niemców jako czynnika służącego „konfrontacji” tego narodu z Żydami ${ }^{69}$. Inny młodokonserwatysta, Heinrich von Gleichen-Russwurm, twierdził w artykule Die völkische Frage (1924), że głównym celem niemieckiego nacjonalizmu nie powinno być rozwiązanie tzw. kwestii żydowskiej, lecz dążenie do urzeczywistnienia „woli narodowej” poprzez likwidację demokracji parlamentarnej w Rzeszy i uwolnienie tego państwa od „hańby Wersalu”. Mimo że rewolucyjni konserwatyści - poza tzw. volkistami - na ogół nie eksponowali rasowych właściwości swego narodu, nie wątpili jednak w jego wyjątkowe uzdolnienia mające predestynować Niemców do duchowego i politycznego przywództwa nad innymi narodami. Nie byli natomiast zgodni co do kryterium rozróżnienia pojęć Volk i Nation, posługując się nimi niekiedy zamiennie. Wśród neokonserwatywnych ideologów przeważał pogląd reprezentowany m.in. przez

66 F. Tönnies, Gemeinschaft und Gesellschaft. Grundbegriffe der reinen Soziologie, Berlin 1920, s. 4 i n. Por. H. Plessner, Grenzen der Gemeinschaft. Kritik des sozialen Radikalismus, Bonn 1924, s. 26 i n.

67 M.H. Boehm, Das eigenständige Volk. Volkstheoretische Grundlagen der Ethnopolitik und Geisteswissenschaften, Göttingen 1932.

68 Por. H. Kessler, Wilhelm Stapel als politischer Publizist. Ein Beitrag zur Geschichte des konservativen Nationalismus zwischen beiden Weltkriegen, Nürnberg 1976, s. 166 i n.; H. Olszewski, Nauka historii..., s. 139; H. Schleier, Burżuazyjna historiografia w Niemczech weimarskich, Warszawa 1985, s. 352.

69 A. Moeller van den Bruck, Die Deutschen, Bd. 7, Minden 1904, s. 309. 
Junga, że Volk oznacza „organizm” oparty na tradycji i więzach krwi, Nation stanowi zaś „uformowaną przez państwo masę społeczną" "70. Moeller van den Bruck definiował Nation jako „wspólnotę wartości” (Wertungsgemeinschaft) rozwijaną przez członków tej zbiorowości dzięki wynikającej z nacjonalizmu świadomości narodowej odrębności. Upatrując w państwie czynnik warunkujący formowanie się Nation, rewolucyjni konserwatyści wyrażali przekonanie, że Niemcy przestali być zwłaszcza po I wojnie światowej tak pojmowanym narodem, gdyż ówczesne państwo niemieckie nie potrafiło sprostać ciążącemu na nim obowiązkowi zintegrowania społeczeństwa. Omawiana doktryna wysuwała zatem postulat przekształcenia Volk w Nation, w czym upodabniała się nieco do przedstawionych na początku XX w. koncepcji konserwatywnego historyka Friedricha Meineckego, dzielącego narody na kulturalne (Kulturnationen) i państwowe (Staatsnationen) ${ }^{71}$.

$\mathrm{Z}$ nacjonalistycznych $\mathrm{i}$ antyliberalnych przesłanek wynikało znamienne dla rewolucyjnego konserwatyzmu w Republice Weimarskiej dążenie do wykazania duchowego pokrewieństwa i wspólnoty interesów między Niemcami a Rosjanami, stanowiące konsekwencję przyjętego w omawianej ideologii odróżnienia kultury „Wschodu” i „Zachodu”. Na przeciwstawieniu tych dwóch systemów wartości zaważyło geopolityczne położenie Rzeszy między uchodzącą w neokonserwatywnej doktrynie za spadkobierczynię ,zasad roku 1789” Francją a przeżywającą po 1917 r. okres burzliwych przemian społeczno-politycznych Rosją. Dodajmy, że niektórzy rewolucyjni konserwatyści, szczególnie reprezentanci tzw. narodoworewolucyjnego odłamu neokonserwatywnej ideologii, niemal z podziwem wyrażali się o rewolucji październikowej, dostrzegając w niej „najbardziej znaczące politycznie wydarzenie w XX w.”72. W geopolitycznym układzie warunkującym neokonserwatywną koncepcję kulturalnego antagonizmu Wschód-Zachód w ogóle nie liczyła się Polska, którą rewolucyjni konserwatyści uważali za efemeryczny twór państwowy uzależniony od byłych mocarstw Ententy i mający w przyszłości stanowić łup Niemiec. Według pozostającego pod wpływem neokonserwatywnej doktryny wiedeńskiego profesora socjologii w latach międzywojennych, Othmara Spanna, różnica między „Wschodem” a „Zachodem” sprowadzała się do sprzeczności między uniwersalizmem (znamiennym zwłaszcza dla Niemców) a indywidualizmem (charakterystycznym dla narodów przywiązanych do zasad demo-

70 E.J. Jung, Die Herrschaft der Minderwertigen..., s. 114-115 i n.; idem, Föderalismus aus Weltanschuung, München 1931, s. 21. Por. B. Jenschke, Zur Kritik der konservativ-revolutionären Ideologie in der Weimarer Republik. Weltanschauung und Politik bei Edgar Julius Jung, München 1971, s. 92 i n.

${ }^{71} \mathrm{Na}$ temat tego podziału por. H. Olszewski, Friedrich Meinecke. Z dziejów ideologii konserwatyzmu w Niemczech, [w:] Studia z dziejów myśli politycznej w Niemczech XIX i XX wieku, red. H. Olszewski, Poznań 1982, s. 147.

72 Por. K. Prümm, op. cit., s. 48-49; O.F. Schüddekopf, op. cit., s. 35 i n. 
kracji parlamentarnej $)^{73}$. Dążenie niektórych rewolucyjnych konserwatystów do wytyczenia nierzadko sztucznej granicy między wartościami „Wschodu” i „Zachodu” wyraziło się w podkreślaniu przez nich (m.in. przez E. Niekischa, H. Plassa, F. Schauweckera) podobieństwa sytuacji Rzeszy i Rosji Radzieckiej w międzynarodowych stosunkach po I wojnie światowej. W opinii przedstawicieli narodoworewolucyjnego nurtu „rewolucji konserwatywnej” ZSRR był „największym antywersalskim mocarstwem światowym”, w równym stopniu co Niemcy zainteresowanym obaleniem europejskiego porządku po 1918 r. $^{74}$ W ,agresywnej” i ,imperialistycznej” polityce państw zachodnioeuropejskich wobec Rzeszy i Rosji Radzieckiej neokonserwatywna doktryna dostrzegała przesłankę współdziałania tych dwóch krajów. Z postulatem nawiązania między nimi współpracy wystąpił już w 1919 r. nacjonalistyczny pisarz polityczny Paul Eltzbacher, którego poglądy stały się podstawą rozwoju w Rzeszy nurtu ideologicznego o nasuwającej rozmaite skojarzenia propagandowe nazwie „narodowy bolszewizm" (Nationalbolschewismus) $)^{75}$.

Filozoficzne i polityczne motywacje tezy o duchowym pokrewieństwie Niemiec i Rosji odnaleźli neokonserwatywni intelektualiści Rzeszy w antyliberalnych i przepojonych chrześcijańskim mistycyzmem oraz bliskich nihilizmowi i nacjonalizmowi zapatrywaniach Fiodora M. Dostojewskiego. Ten rosyjski pisarz, obok Nietzschego, wywarł znaczny wpływ na kształtowanie się doktryny rewolucyjnego konserwatyzmu ${ }^{76}$. Z koncepcji Dostojewskiego miał Moeller van den Bruck wyprowadzić formułę pozwalającą na skojarzenie ze sobą słów „rewolucja” i „konserwatyzm”. We wstępie do niemieckiej edycji dzieł rosyjskiego myśliciela autor Das dritte Reich dowodził, że Niemcy potrzebują „,bezwarunkowej duchowości rosyjskiej” w celu uwolnienia się od „zapatrzenia na Zachód” i odnalezienia tożsamości narodowej ${ }^{77}$. Choć Rzeszę i Rosję łączy „wspólny los”, to jednak Niemcy powinni zachować ,„pewien dystans” w stosunkach ze swym wschodnim sąsiadem, aby nie popaść w zależność od niego. Moeller van den Bruck opowiadał się bowiem - nie będąc w tym odosobniony wśród rewolucyjnych konserwatystów - za osiągnięciem przez Rzeszę takiej pozycji w stosun-

73 O. Spann, Der wahre Staat. Vorlesungen itber Anbruch und Neubau der Gesellschaft, Leipzig 1921, s. 95 i n. Analogicznie ujmował tę różnicę E. Niekisch, Die Politik des deutschen Widerstandes, „Widerstand“ 1930, Heft 4 (April), s. 97 i n.

74 O.F. Schüddekopf, op. cit., s. 280.

75 P. Eltzbacher, Der Bolschewismus und die deutsche Zukunft, Jena 1919. Por. L. Dupeux, „Nationalbolschewismus “ in Deutschland 1919-1933. Kommunistische Strategie und konservative Dynamik, München 1985, s. 41 i n.

76 Por. L. Loewenthal, Die Auffassung Dostojewskis im Vorkriegsdeutschland, „Zeitschrift für Sozialforschung“ 1934, Heft 3, s. 343; K.-G. Kaltenbrunner, Von Dostojewski zum Dritten Reich. Arthur Moeller van den Bruck und die „, konservative Revolution “, „Politische Studien“ 1969, Heft 184, s. $188-189$.

77 F.M. Dostojewski, Sämtliche Werke, Bd. 1, München 1922, s. VI. 
kach międzynarodowych, która zapewniałaby jej realizację własnego kierunku rozwoju ${ }^{78}$. Reprezentowana przez autora Das dritte Reich i innych neokonserwatystów „wschodnia” orientacja polityczna wcale nie była jednoznaczna z aprobatą dla teorii i praktyki bolszewizmu, lecz wynikała z poszukiwania wpływowych sojuszników w walce $\mathrm{z}$ liberalizmem prowadzonej pod hasłem obrony narodowych interesów niemieckich. Z tego względu postulat współdziałania z ZSRR nie wykluczał nacjonalistycznych implikacji neokonserwatywnej doktryny, a zwłaszcza jej antykomunistycznych założeń, choć niektórzy przedstawiciele tej ideologii zbliżali się w swych poglądach do koncepcji tzw. naukowego socjalizmu. Nacjonalistycznym celom rewolucyjnego konserwatyzmu służyła zapożyczona od Dostojewskiego idea tzw. młodych narodów: niemieckiego, rosyjskiego i północnoamerykańskiego. Na niej Moeller van den Bruck oparł swe rozważania zawarte w pracy Das Recht der jungen Völker z 1919 r., starając się udowodnić, że o rozwoju dziejów nie będą już decydować Francuzi czy Anglicy, lecz właśnie narody dotychczas nieodgrywające znacznej roli historycznej. Również Spengler uważał Niemców i Rosjan za „młode” narody odznaczające się witalnością i dynamizmem ${ }^{79}$. Ten rewolucyjny konserwatysta nie wykluczał jednak możliwości konfliktu między nimi na skutek narastających sprzeczności politycznych i ekonomicznych interesów Rzeszy i ZSRR. Pisząc o tym w niedokończonej rozprawie Jahre der Entscheidung (1933), przewidywał walkę o panowanie nad światem dwóch „rewolucji”: białej i kolorowej. Będący niemal entuzjastą przemian w ZSRR Niekisch kreślił natomiast już w okresie Republiki Weimarskiej wizję „germańsko-słowiańskiej Rzeszy światowej” jako rezultatu przymierza niemiecko-radzieckiego ${ }^{80}$. W ewentualnym sojuszu tych państw dostrzegał przejaw symbiozy interesów dwóch „rewolucyjnych nacjonalizmów”.

$\mathrm{Na}$ podstawie ukazanych założeń rewolucyjnego konserwatyzmu można sedno tej doktryny ująć jako antytezę niemal wszystkich uważanych za postępowe nurtów filozoficznych i politycznych od czasów nowożytnych po wiek XX. Szczególnie krytycznie odnosiła się ona do koncepcji rewolucji francuskiej przełomu XVIII i XIX w., upatrując w propagowanych przez nią hasłach mieszczańskiego liberalizmu zagrożenia dla wartości narodowych. Z nacjonalistycznych przesłanek wyrastała również negacja przez rewolucyjnych konserwatystów tych

78 Por. A. Moeller van den Bruck, Das Recht der jungen Völker. Sammlung politischer Aufsätze, Berlin 1932, s. 81 i n. Por. E. Niekisch, Gedanken über deutsche Politik, Dresden 1929, s. 28, 30; E.J. Jung, Revolutiondre Aussenpolitik, „Deutsche Rundschau“ 1932 (Februar), s. 90.

79 G.L. Ulmen, Metaphysik und Morgenlandes - Spengler über Russland, [w:] Spengler heute. Sechs Essays, Hrsg. P.Ch. Ludz, München 1980, s. 145 i n.

${ }^{80}$ E. Niekisch, Russland-Italien-Deutschland, „Widerstand“ 1926, Heft 6 (Juni), s. 54. Por. U. Sauermann, Die Zeitschrift ,Widerstand“ und ihrer Kreis. Die publizistische Entwicklung eines Organs des extremen Nationalismus und sein Wirkungsbereich in der politischen Kultur Deutschlands 1926-1934, Augsburg 1984, s. 271. 
bezpośrednio niezwiązanych z „zasadami roku 1789” doktryn politycznych (m.in. marksizmu i anarchizmu), które nie traktowały narodu jako najważniejszego dobra, lecz za cel stawiały sobie osiągnięcie „szczęścia” dla ogółu ludzkości bądź dla określonej grupy społecznej. Za Fritzem Sternem można przyjąć, że neokonserwatyzm w Republice Weimarskiej stanowił ,ideologiczny atak na nowoczesność, na zespół idei i instytucji właściwych cywilizacji przemysłowej"81. Reprezentowana przez rewolucyjnych konserwatystów postawa wobec otaczającej rzeczywistości społeczno-politycznej odznaczała się antymodernizmem, charakterystycznym zresztą dla wszelkiego rodzaju konserwatywnego poglądu na świat. Tę cechę neokonserwatywnej doktryny w Republice Weimarskiej podkreśla wielu autorów ${ }^{82}$. Niektórzy z nich chętnie nawiązują do tezy Sterna, że wrogi stosunek rewolucyjnych konserwatystów do „nowoczesności” stanowił przejaw znamiennego dla mentalności nie tylko niemieckich warstw inteligenckich po I wojnie światowej „kulturalnego pesymizmu" (Kulturpessimismus), wynikającego m.in. z pogłębiania się w tym okresie antagonizmów społecznych na skutek rozwoju stosunków kapitalistycznych, które przyczyniły się do kryzysu wzorców moralności mieszczańskiej.

Niemal totalna negacja doktryn od renesansu i reformacji, poprzez oświecenie i rewolucję francuską, do liberalizmu, pozytywizmu, anarchizmu i innych opartych na racjonalistycznych i materialistycznych przesłankach systemów ideologicznych upodabniała myśl neokonserwatywną w Niemczech weimarskich do założeń „klasycznego" konserwatyzmu dziewiętnastowiecznego. W opinii niemieckiego badacza Martina Greiffenhagena „rewolucja konserwatywna” była „ostatnią fazą specyficznie niemieckiego konserwatyzmu w swej absurdalności bez wyjścia" ${ }^{" 33}$. O ile bowiem „starzy” konserwatyści z ubiegłego stulecia skłaniali się - ze względu na rosnące wpływy polityczne klasy robotniczej - ku przymierzu z liberałami, o tyle „nowi” konserwatyści w Republice Weimarskiej w ogóle odrzucali mieszczańską ideologię demokratyczną, a nawet starali się niekiedy nadać swej doktrynie antykapitalistyczny wydźwięk. W odróżnieniu od tradycyjnego konserwatyzmu nie wszyscy rewolucyjni konserwatyści opowiadali się za całkowitą nienaruszalnością własności prywatnej i opartych na niej stosunków społecznych, lecz postulowali dokonanie zmian $\mathrm{w}$ tej dziedzinie poprzez wprowadzenie wynikającego $\mathrm{z}$ nacjonalistycznych i solidarystycznych przesłanek tzw. niemieckiego lub pruskiego socjalizmu. Za pożądane uważali nawet przyspieszenie przeobrażeń status quo w sferze społecznej i politycznej przy użyciu odrzucanych przez „klasyczny” kon-

81 F. Stern, Kulturpessimismus als politische Gefahr. Eine Analyse nationaler Ideologie in Deutschland, Bern-Stuttgart-Wien 1963, s. 7.

82 Por. zwłaszcza referaty z sympozjum w Strasburgu (1981) na temat „Kulturpessimismus, Revolution conservatrice et modernite” opublikowane w „Revue d'Auemagne“" 1982, Bd. 14, Heft 1.

83 M. Greiffenhagen, Das Dilemma ..., s. 243-244; idem, Post-historie? Bemerkungen zur Situation des „Neokonservatismus “, [w:] Die Neue Gesellschaft, „Frankfurter Hefte“ 1986, Heft 10, s. 902 . 
serwatyzm dziewiętnastowieczny metod opartych na sile i przemocy. Na dążeniu do urzeczywistnienia gwałtownych przemian polegał radykalizm neokonserwatywnej doktryny w Niemczech po 1918 r. Miejsce powolnych reform zajęła w niej instrumentalnie pojmowana „rewolucja”, której celem miało być „przewartościowanie wszystkich wartości" (Umwertung aller Werte) z wyjątkiem - jak pisał Moeller van den Bruck w Das dritte Reich - wartości ,godnych zachowania” (jak naród, ojczyzna, honor itp.). Jung za takie uważał wartości gwarantujące ,związek człowieka z naturą i Bogiem". W przekonaniu tego neokonserwatysty rewolucja o cechach konserwatywnych polegałaby na zastąpieniu dążenia ludzi do równości „sprawiedliwym układem” w społeczeństwie, „biurokratycznego przymusu - wewnętrzną odpowiedzialnością prawdziwego samorządu”, idei „mechanicznego wyboru” - zasadą „organicznego” kierownictwa, a koncepcji szczęścia ludu - „prawem osobowości narodu" "84. Opierając się na takich założeniach, „rewolucja” oznaczała zatem antydemokratyczne przeobrażenia społeczno-polityczne zmierzające do ukształtowania hierarchicznej pod względem wewnętrznej struktury wspólnoty narodowej Niemców rządzonej przez niepochodzącą z parlamentarnych wyborów elitę sprawującą autorytarną władzę w interesie całej Volksgemeinschaft. Niektórzy neokonserwatywni ideologowie (m.in. C. Schmitt) nie wykluczali możliwości współudziału społeczeństwa w rządzeniu państwem poprzez zastosowanie form demokracji bezpośredniej, odrzucając natomiast wszelkie instytucje przedstawicielskie, gdyż podważały one ,zaufanie mas do politycznego kierownictwa" 85 . Dla wspomnianego F.G. Jüngera „,demokratyczne” było to, „,czego chce naród”. Pojęcie demokracji uważał za „pojęcie blankietowe”, które „,dzięki określonej woli narodu otrzymuje konkretną treść". W związku z taką interpretacją istoty demokracji w neokonserwatywnej doktrynie pojawiały się koncepcje „,narodowej dyktatury”, realizującej „wolę powszechną" poprzez konsolidację wszystkich elementów społeczeństwa w celu urzeczywistnienia ,rewolucji konserwatywnej”"86. Przepojone nacjonalizmem koncepcje rewolucyjnych konserwatystów dotyczące funkcjonowania państwa i społeczeństwa kształtowały się poniekąd pod naporem dylematu: utrzymywać czy niszczyć istniejący status quo.

Gdyby określić jako „rewolucyjny” stosunek tej doktryny do instytucji ustrojowych Republiki Weimarskiej, to za „konserwatywną” należałoby uznać posta-

${ }^{84}$ E.J. Jung, Deutschland..., s. 380.

85 Por. H. Grüneberg, Zur Theorie des Antiparlamentarismus, „Die Tat“ 1930, Heft 2, s. 120. C. Schmitt (Romantik, „Hochland“ 1924/1925, Nr. 22, s. 171 i n.) dowodził, że stanowiące istotę parlamentaryzmu swobodne ścieranie się poglądów politycznych i kontrola opinii publicznej nad rządem były uzasadnione w okresie walki z monarchią absolutną, lecz straciły rację bytu w warunkach totalnej organizacji społeczeństwa od schyłku XIX w.

86 Por. H. Grüneberg, Warum Diktatur?, „Die Tat“ 1930, Heft 5, s. 332; F.G. Jünger, Das Gesicht der Demokratie, Leipzig 1931; G. Günther, Das werdende Reich. Reichsgeschichte und Reichsrejorm, Hamburg 1932. 
wę neokonserwatystów wobec takich wartości, jak naród, władza, rodzina. Hasło gwałtownych przeobrażeń społeczno-politycznych starali się oni pogodzić z ideami konserwatywnymi przez zastosowanie formuły cyklicznego rozwoju dziejów, który miałby polegać na okresowym powrocie do „stałych wartości” wraz z powtarzającymi się „obrotami koła” historii ${ }^{87}$. Ze względu na przywiązanie do tych wartości i negację wielu nurtów politycznych od czasów nowożytnych po XX w. neokonserwatyści niemieccy po I wojnie światowej byli bardziej konserwatystami niż rewolucjonistami. Nie chodziło im jednak o przywrócenie status quo ante, czyli o powrót do okresu sprzed wybuchu I wojny światowej, który i tak wydawał się tym intelektualistom wspaniały w porównaniu z czasami Republiki Weimarskiej. Swymi poglądami na państwo czy społeczeństwo rewolucyjni konserwatyści wyraźnie wybiegali w przyszłość, opowiadając się za „przeskokiem” nad demokracją parlamentarną ku czemuś, co byłoby jej zupełnym zaprzeczeniem i przeciwieństwem, czyli do dyktatury wspartej na przesłankach nacjonalistycznych. W owym dążeniu do czegoś absolutnie innego niż system weimarski zapewne manifestował się rewolucjonizm omawianej doktryny. Jej przedstawiciele tak bardzo nienawidzili tego ustroju, że byli skłonni poprzeć każdego (może z wyjątkiem komunistów), kto stwarzał nadzieję na jego obalenie. To dlatego przynajmniej część z nich sprzyjała nazistom, a nawet starała się ich wspierać politycznie.

Na przykładzie omówionej doktryny można zauważyć przynajmniej częściowe zacieranie się różnic, które jeszcze pod koniec XIX stulecia uzasadniały podział politycznych i społecznych koncepcji na niewątpliwie prawicowe i bezsprzecznie lewicowe. Wraz z nastaniem rządów nazistowskich w Niemczech w 1933 r. rewolucyjny konserwatyzm przestał stanowić samodzielny i wpływowy nurt intelektualno-polityczny. Na koniec warto nadmienić, że wielu jego reprezentantów przeszło jednak na „służbę” nowego reżimu, przyczyniając się swoimi poglądami (w tym koncepcjami nacjonalistycznymi) do uzasadniania wewnętrznej i zagranicznej polityki władz Trzeciej Rzeszy.

\section{BIBLIOGRAFIA}

Aufstand. Querschnitt durch den revolutionären Nationalismus, Hrsg. G.O. Stoffregen, Berlin 1931. Bartyzel J., Prawica - nacjonalizm - monarchizm. Studia politologiczno-historyczne, RadzyminWarszawa 2016.

Bein S., Der Arbeiter. Typus - Name - Gestalt, [w:] Wandlung und Wiederkehr. Festsschrift zum 70. Geburtstag Ernst Jüngers, Hrsg. H.L. Arnold, Aachen 1965.

Benjamin W., Teorie niemieckiego faszyzmu. O pracy zbiorowej pt. Wojna i wojujacy, pod redakcja Ernsta Jüngera, [w:] Walter Benjamin, Gottfried Benn, Ernst Bloch, Bertolt Brecht, Hermann Broch, Elias Canetti, Max Horkheimer, Theodor W. Adorno, Victor Klemperer, Siegfried Krac-

87 Por. A. Mohler, op cit., s. 115-116; J. Krasuski, Historia Rzeszy Niemieckiej 1871-1945, Poznań 1971, s. 269; idem, Z dziejów niemieckiej myśli politycznej XIX i XX wieku. Eseje filozoficzno-historyczne, Poznań 1965, s. 204-205. 
kauer, Karl Kraus, Heinrich Mann, Klaus Mann, Thomas Mann, Joseph Roth, Friedrich Wolf wobec faszyzmu, wyb. i wstęp H. Orłowski, Warszawa 1987.

Bernhardi F., Germany and the Next War, New York 1914.

Boehm M.H., Das eigenständige Volk. Volkstheoretische Grundlagen der Ethnopolitik und Geisteswissenschaften, Göttingen 1932.

Breuer S., Anatomie der Konservativen Revolution, Darmstadt 1993.

Buchheim H., Ernst Niekischs Ideologie des Widerstandes, „Vierteljahrshefte fur Zeitgeschichte“ 1957, Heft 4

Bussmanh W., Politische Ideologien zwischen Monarchie und Weima er Republik. Ein Beitrag zur Ideengeschichte der Weimarer Republik, „Historische Zeitschrift“ 1960, Bd. 190.

Chwalba A., Samobójstwo Europy. Wielka wojna 1914-1918, Warszawa 2014.

Clemens G., Martin Spahn und der Rechtskatholizismus in der Weimarer Republik, Mainz 1983.

Der Kampf um das Reich, Hrsg. E. Jünger, Essen 1929.

Dostojewski F.M., Sämtliche Werke, Bd. 1, München 1922.

Droste V., Ernst Jünger: „,Der Arbeiter“. Studien zu seiner Metaphysik, Mainz 1980.

Dupeux L., „Nationalbolschewismus “ in Deutschland 1919-1933. Kommunistische Strategie und konservative Dynamik, München 1985.

Eksteins M., Święto wiosny. Wielka wojna i narodziny nowego wieku, Poznań 2014.

Eltzbacher P., Der Bolschewismus und die deutsche Zukunft, Jena 1919.

Faber R., Roma aeterna. Zur Kritik der ,Konservativen Revolution“, Würzburg 1981.

Freyer H., Revolution von rechts, Jena 1931.

Fritsche K., Politische Romantik und Gegenrevolution. Fluchtwege in der Krise der bürgerlichen Gesellschaft: das Beispiel des ,Tat"-Kreises, Frankfurt am Main 1976.

Galera K.S., Das junge Deutschland und das Dritte Reich, Leipzig 1932.

Gerhart W., Um das Reiches Zukunft. Nationale Wiedergeburt oder politische Reaktion?, Freiburg im Breisgau 1932.

Gerwarth R., Pokonani. Dlaczego pierwsza wojna światowa się nie zakończyła (1917-1923), Poznań 2017.

Gilbert M., Pierwsza wojna światowa, Poznań 2003.

Greiffenhagen M., Das Dilemma des Konservatismus in Deutschland, München 1971.

Greiffenhagen M., Post-historie? Bemerkungen zur Situation des „,Neokonservatismus “, [w:] Die Neue Gesellschaft, „Frankfurter Hefte“ 1986, Heft 10.

Greven M.T., Konservative Kultur-und Zwilisationskritik in „Dialektik der Aufklärung“ und „, Schwelle der Zeiten “, [w:] Konsenatismus - eine Gefahr fur die Freiheit?, Hrsg. E. Henning, R. Saage, München-Zürich 1983.

Groh D., Negative Integration und revolutionärer Attentismus, Frankfurt am Main 1973.

Gründel E.G., Die Sendung der Jungen Generation. Versuch einer umfassenden revolutionären Sinndeutung der Krise, München 1933.

Grüneberg H., Warum Diktatur?, „Die Tat“ 1930, Heft 5.

Grüneberg H., Zur Theorie des Antiparlamentarismus, „Die Tat“ 1930, Heft 2.

Günther G., Das werdende Reich. Reichsgeschichte und Reichsrejorm, Hamburg 1932.

Ham P., 1914. Rok końca świata, Warszawa 2015.

Hansen H., Die ungelöste Revolution, „Standarte“ 1927, Heft 1.

Hausmann C., Europas Krieg, „März“, 22 VIII 1914.

Hecker H., ,Die Tat“ und ihr Osteuropabild 1909-1939, Koln 1974.

Heinz W., Die Nation greift an: Geschichte und Kritik des soldatischen Nationalismus, Berlin 1933.

Heuss T., Der Weltkrieg, „März“, 5 VIII 1914.

Hietala M., Der neue Nationalismus in der Publizistik Ernst Jüngers und des Kreises um ihn 19201933, Helsinki 1975.

Hofmannsthal H. von, Das Schrifttum als geistiger Raum der Nation, München 1921.

Holzer J., Europa wojen 1914-1945, Warszawa 2008. 
Hürlimann M., Berlin, Zürich 1981.

Jenschke B., Zur Kritik der konservativ-revolutionären Ideologie in der Weimarer Republik. Weltanschauung und Politik bei Edgar Julius Jung, München 1971.

Jung E.J., Deutschland und die konservative Revolution, [w:] Deutsche über Deutschland. Die Stimme des unbekannten Politikers, München 1931.

Jung E.J., Die Herrschaft der Minderwertigen. Ihr Zerfall und ihre Ablösung durch ein Neues Reich, Berlin 1930.

Jung E.J., Föderalismus aus Weltanschuung, München 1931.

Jung E.J., Revolutiondre Aussenpolitik, „Deutsche Rundschau“ 1932 (Februar).

Jung E.J., Sinndeutung der deutschen Revolution, Oldenburg 1933.

Jünger E., Der Arbeiter. Herrschaft und Gestalt, Hamburg 1932.

Jünger E., Der Kampf als innere Erlebnis, Berlin 1922.

Jünger E., Der unsichtbare Kern, „Der Vormarsch“ 1929, Heft 11.

Jünger E., Die Kriegsschuld des Bürgers, „Die Sozialistische Nation“ 1932, Heft 8/9 (September).

Jünger E., Die totale Mobilmachung, Berlin 1931.

Jünger E., In Stahlgewittern. Aus dem Tagebuch eines Stosstruppführers, Berlin 1942.

Jünger E., ,, Nationalismus “ und Nationalismus, „Das Tagebuch“ 1929, Heft 38 (September).

Jünger E., Publicystyka polityczna 1919-1936, Kraków 2007.

Jünger E., Robotnik. Panowanie i forma bytu. Maksima - minima, Warszawa 2010.

Jünger F.G., Das Gesicht der Demokratie, Leipzig 1931.

Jünger F.G., Die Kampfbünde, „Standarte“ 1926, Heft 1.

Jünger F.G., Die Perfektion der Technik, Frankfurt am Main 1949.

Jünger F.G., Krieg und Krieger, Hrsg. E. Jünger, Berlin 1930.

Kabermann F., Widerstand und Entscheidung eines deutschen Revolutionars. Leben und Denken von Ernst Niekisch, Köln 1973.

Kaltenbrunner K.-G., Von Dostojewski zum Dritten Reich. Arthur Moeller van den Bruck und die „konservative Revolution“, „Politische Studien“ 1969, Heft 184.

Kershaw I., Do piekła i z powrotem. Europa 1914-1949, Kraków 2016.

Kessler H., Wilhelm Stapel als politischer Publizist. Ein Beitrag zur Geschichte des konservativen Nationalismus zwischen beiden Weltkriegen, Nürnberg 1976.

Kleinau W., Stahlhelm und Staat, Berlin 1929.

Klemperer K. von, Germany's New Conservatism: Its History and Dilemma in the Twentieth Century, New Jersey 1968.

Klintzsch U., Führer und Gefolgschaft, „Der Vormarsch“ 1928, Heft 9.

Klotzbücher A., Der politische Weg des Stahlhelms, Bund der Frontsoldaten, in der Weimarer Republik. Ein Beitrag zur Geschichte des ,Nationalen Opposition“ 1918-1933, Erlangen 1965.

Krasuski J., Historia Rzeszy Niemieckiej 1871-1945, Poznań 1971.

Krasuski J., Z dziejów niemieckiej myśli politycznej XIX i XX wieku. Eseje filozoficzno-historyczne, Poznań 1965.

Lawrance P., Nacjonalizm. Historia i teoria, Warszawa 2007.

Legarde P. de, Deutsche Schriften, München 1934.

Loewenthal L., Die Auffassung Dostojewskis im Vorkriegsdeutschland, „Zeitschrift für Sozialforschung" 1934, Heft 3.

Loose G., Ernst Jünger. Gestalt und Werk, Frankfurt am Main 1957.

Maciejewski M., Doktryna rewolucyjnego konserwatyzmu wobec narodowego socjalizmu 19211945, Wrocław 1991.

Maciejewski M., Koncepcja Trzeciej Rzeszy Arthura Moellera van den Brucka, „Studia nad Faszyzmem i Zbrodniami Hitlerowskimi” 1980, t. 6.

Maciejewski M., Niemieckie elity a hitleryzm. O stosunku rewolucyjnych konserwatystów do nazizmu w Rzeszy demokratycznej i hitlerowskiej, Wrocław 1994. 
Mahraun A., Das Jungdeutshe Manifest. Volk gegen Kaste und Geld. Sicherung des Friedens durch Neubau der Staaten, Berlin 1928.

Mann T., Betrachtungen eines Unpolitischen, Berlin 1918.

Mann T., Czarodziejska góra, Warszawa 1956.

Mann T., Friedrich und die grosse Koalition, Berlin 1916.

Mann T., Kultur und Sozialismus, [w:] Gesammelte Werke, Bd. 12, Berlin 1965.

Mann T., Russische Anthologie, [w:] Gesammelte Werke, Bd. 9, Frankfurt am Main 1960.

Maste E., Die Republik der Nachbarn. Die Nachbarschaft und der Staatsgedanke Arthur Mahrauns, Giessen 1957.

Mauch H.-J., Nationalistische Wehrorganisationen in der Weimarer Republik. Zur Entwicklung und Ideologie des ,,Paramilitarismus “, Frankfurt am Main 1982.

Meinecke F., Strassburg - Freiburg - Berlin, Stuttgart 1949.

Miziński J., Filozofia wojny w literaturze nacjonalizmu żotnierskiego ze szczególnym uwzględnieniem twórczości Ernsta Jüngera, „Kultura i Społeczeństwo” 1978, nr 4.

Moeller van den Bruck A., Das dritte Reich, Hamburg 1931.

Moeller van den Bruck A., Das Recht der jungen Völker. Sammlung politischer Aufsätze, Berlin 1932.

Moeller van den Bruck A., Die Deutschen, Bd. 7, Minden 1904.

Moeller van den Bruck A., Jedes Volk hat seinen eigenen Sozialismus, Oldenburg 1931.

Mohler A., Die konservative Revolution in Deutschland. Grundriss ihrer Weltanschauung, Stuttgart 1950.

Momber E., 's ist Krieg! 's ist Krieg! Versuch zur Literatur über den Krieg 1914-1933, Berlin 1981.

Nacjonalizmy różnych narodów. Perspektywa politologiczno-religioznawcza, red. B. Grott, O. Grott, Kraków 2012.

Niekisch E., Die Politik des deutschen Widerstandes, „Widerstand“ 1930, Heft 4 (April).

Niekisch E., Gedanken über deutsche Politik, Dresden 1929.

Niekisch E., Russland - Italien - Deutschland, „Widerstand“ 1926, Heft 6 (Juni).

Orłowski H., Friedrich Meinecke. Z dziejów ideologii konserwatyzmu w Niemczech, [w:] Studia $z$ dziejów myśli politycznej w Niemczech XIX i XX wieku, red. H. Olszewski, Poznań 1982.

Olszewski H., Nauka historii w upadku. Studium o historiografii i ideologii historycznej w imperialistycznych Niemczech, Warszawa-Poznań 1982.

Orłowski H., Pierwsza wojna światowa w literaturze niemieckiej lat 1919-1933, „Przegląd Zachodni" 1968, nr 4.

Pajewski J., Pierwsza wojna światowa 1914-1918, Warszawa 2009.

Papen F. von, Appel an das deutschen Gewissen. Reden zur nationalen Revolution, Oldenburg 1933.

Petzold J., Die Dolchstosslegende. Eine Geschichtsfälschung im Dienst des deutschen Imperiatismus und Militarismus, Berlin 1963.

Petzold J., Konservative Theoretiker des deutschen Faschismus. Jungkonservative Ideologen in der Weimarer Republik ais geistige Wegbereiter der faschistischen Diktalur, Berlin 1978.

Plenge J., 1789 und 1914. Die symbolischen Jahren in der Geschichte des politischen Geistes, Berlin 1916.

Plessner H., Grenzen der Gemeinschaft. Kritik des sozialen Radikalismus, Bonn 1924.

Prümm K., Die Literatur des soldatischen Nationalismus der 20er Jahre (1918-1933). Gruppenideologie und Epochenproblematik, Bd. 1, Kronberg Taunus 1974.

Rewolucja konserwatywna w Niemczech 1919-1933, wstęp i wyb. W. Kunicki, Poznań 1999.

Riezler K., Tagebücher, Aufsätze, Dokumente, Hrsg. K.D. Erdmann, Göttingen 1972.

Rohan K.A., Die Aufgabe unserer Generation, Köln 1926.

Rosenberg A., Dolchstossdokumente. Zeugnisse der Vorbereitung zur Revolte am 9. November 1918, München 1926.

Rudolph H., Kulturkritik und der konservativen Revolution. Zum kulturell-politischen Denken Hofmannsthals und seinem problemgeschichtlichen Kontext, Tübingen 1971. 
Ryszka F., Intelektualiści a hitleryzm (Szkic o „,rewolucji konserwatywnej” w Niemczech), „Kwartalnik Historyczny" 1959, nr 2.

Ryszka F., Państwo stanu wyjątkowego. Rzecz o systemie państwa i prawa Trzeciej Rzeszy, Wrocław 1974.

Sauermann U., Die Zeitschrift „,Widerstand“ und ihrer Kreis. Die publizistische Entwicklung eines Organs des extremen Nationalismus und sein Wirkungsbereich in der politischen Kultur Deutschlands 1926-1934, Augsburg 1984.

Sauermann U., Ernst Niekisch. Zwischen allen Fronten, München-Berlin 1980.

Schafer D., Die werden wir ein Volk? Wie konnen wir es bleiben?, München 1919.

Schauwecker F., Der Aufbruch der Nation aus dem Kriege, [w:] Deutscher Aufstand. Die Revolution des Nachkriegs, Hrsg. C. Hotzel, Stuttgart 1934.

Schauwecker F., Verwandlung der Seele, [w:] Aufstand. Querschnitt durch den revolutionären Nationalismus, Hrsg. G.O. Stoffregen, Berlin 1931.

Schauwecker F., Wesen des Nationalismus, „Standarte“ 1926, Heft 16.

Scheler M., Der Genius des Krieges und der Deutsche Krieg, Leipzig 1915.

Schleier H., Burżuazyjna historiografia w Niemczech weimarskich, Warszawa 1985.

Schmitt C., Die geistesgeschichtliche Lage des heutigen Parlamentarismus, München-Leipzig 1923.

Schmitt C., Romantik, „Hochland“ 1924/1925, Nr. 22.

Schüddekopf O.F., Linke Leute von rechts. Die nationalrevolutionären Minderheiten und der Kommunismus in der Weimarer Republik, Stuttgart 1960.

Schwierskott H.-J., Arthur Moeller van den Bruck und der revolutionären Nationalismus in der Weimarer Republik, Göttingen 1962.

Sieferle R.P., Die konservative Revolution. Fünf biographische Skizzen, Frankfurt am Main 1995.

Sombart W., Händler Und Helden. Patriotische Besinnungen, München-Leipzig 1915.

Sonn W., Der Mensch im Arbeitszeitalter. Das Werk E. Jüngers als Auseinandersetzung mit dem Nihilismus, Saarbrücken 1971.

Sontheimer K., Antidemokratisches Denken in der Weimarer Republik. Die politischen Ideen des deutschen Nationalismus zwischen 1918 und 1933, München 1962.

Sontheimer K., Die Idee des Reiches im polityschen Denken der Weimarer Republik, „Geschichte in Wissenschaft und Unterricht" 1962, Heft 4.

Spann O., Der wahre Staat. Vorlesungen itber Anbruch und Neubau der Gesellschaft, Leipzig 1921.

Spengler O., Briefe 1913-1936, Hrsg. A.M. Koktanek, München 1963.

Spengler O., Der Mensch und die Technik, München 1933.

Spengler O., Der Untergang des Abendlandes. Umrisse einer Morphologie der Weltgeschichte, Bd. 2, München 1922.

Spengler O., Jahre der Entscheidung. Deutschland und die weltgeschichtliche Entwicklung, Bd. 1, München 1933.

Spengler O., Neubau des Deutschen Reiches, München 1924.

Spengler O., Preussentum und Sozialismus, München 1921.

Stadtler E., Die Weltkriegsrevolution, Leipzig 1920.

Stadtler E., Weltkrieg, Welttragödie und Weltbolschewismus, Berlin 1919.

Stahlhelm-Handbuch, Hrsg. F. Schauwecker, Magdeburg 1927.

Stern F., Kulturpessimismus als politische Gefahr. Eine Analyse nationaler Ideologie in Deutschland, Bern-Stuttgart-Wien 1963.

Stutz R., Die politische Entwicklung Eduard Stadtlers von 1918 bis 1933. Ein Beitrag zur Geschichte des Rechtsextremismus in der Weimarer Republik, Jena 1985.

Tönnies F., Gemeinschaft und Gesellschaft. Grundbegriffe der reinen Soziologie, Berlin 1920.

Troeltsch E., Der Historismus und seine Probleme, [w:] Gesammelte Schriften, Bd. 1, Tübingen 1922. 
Troeltsch E., Naturrecht und Humanitdt in der Weltpolitik, [w:] Deutscher Geist und Westeuropa. Gesammelte kulturphilosophische Aufsätze und Reden, Hrsg. H. Baron, Tübingen 1925.

Troeltsch E., Spektatorbriefe. Aufsätze über die Revolution und die Weltpolitik 1918-1922, Tübingen 1924.

Ulmen G.L., Metaphysik und Morgenlandes - Spengler über Russland, [w:] Spengler heute. Sechs Essays, Hrsg. P.Ch. Ludz, München 1980.

W stronę autorytaryzmu. Nacjonalizm integralny Związu Młodych Narodowców 1934-1939, wyb. i oprac. M. Marszał, Kraków 2008.

Wielomski A., Nacjonalizm francuski 1886-1940. Geneza, przemiany i istota filozofii politycznej, Warszawa 2007.

Wiest A., Historia I wojny światowej, Warszawa 2003.

Winnig A., Wir hütten das Feuer. Aufsätze und Reden aus zehn Jahren (1923-1933), Hamburg 1933.

Wirths W., Das Erlebnis des Krieges, [w:] Die Neue Front, Hrsg. A. Moeller van den Bruck, H. von Gleichen, M.H. Boehm, Berlin 1922.

\section{SUMMARY}

In the period directly preceding the outbreak of the so-called Great War, i.e. World War I (summer of 1914), and during its earliest stages, pro-war, patriotic-nationalistic (and not without imperialist connotations) and military ideas started taking shape in Germany, gradually gaining popularity in many political circles. These conceptions embraced the cult of manhood, heroism and sacrifice for the motherland, the so-called socialism of trenches, specific aesthetic and cultural values. These amalgamation of ideas was subjected to the concept of national community (deutsche Volksgemeinschaft) which was central for German nationalist circles. Its goals and purposes were supposed to set the direction of this doctrine's development. After the First World War, the ideas of 1914 were continued and enriched in Germany, despite this country's absolute military defeat in the Great War, by the representatives of revolutionary conservatism. This article discusses their conceptions in this field.

Keywords: war; nationalism; German nation; conservative revolution

\section{STRESZCZENIE}

W okresie bezpośrednio poprzedzającym wybuch tzw. Wielkiej Wojny, czyli I wojny światowej (lato 1914 r.), oraz w początkach jej trwania ukształtowały się w Niemczech, zyskując popularność w wielu środowiskach politycznych, patriotyczno-nacjonalistyczne, militarne, niepozbawione cech imperialistycznych idee prowojenne. Przeszły one do historii myśli politycznej pod nazwą idei roku 1914. Pod tym określeniem kryły się m.in. kult męstwa, bohaterstwa i poświęcenia dla ojczyzny, koncepcje tzw. socjalizmu okopów, określone wartości estetyczne i kulturowe. Wszystko to zostało podporządkowane naczelnej w niemieckich środowiskach nacjonalistycznych idei wspólnoty narodowej (deutsche Volksgemeinschaft). Jej cele i interesy miały wyznaczać kierunki rozwoju tej doktryny. Idee roku 1914 kontynuowali i wzbogacili już po I wojnie światowej w Niemczech mimo klęski militarnej tego państwa w tej wojnie - przedstawiciele rewolucyjnego konserwatyzmu. $\mathrm{O}$ ich koncepcjach w tej dziedzinie traktuje niniejszy artykuł.

Slowa kluczowe: wojna; nacjonalizm; naród niemiecki; rewolucja konserwatywna 